JOURNAL OF

ENVIRONMENTAL QUALITY

\title{
Temperature and Manure Placement in a Snowpack Affect Nutrient Release from Dairy Manure during Snowmelt
}

\begin{tabular}{|r|l|}
\hline Journal: & Journal of Environmental Quality \\
\hline Manuscript ID & JEQ-2017-12-0464-TR.R1 \\
\hline Mechuscript Type: & Technical Research Paper \\
\hline Date Submitted by the Author: & 05-Mar-2018 \\
\hline Complete List of Authors: & $\begin{array}{l}\text { Vadas, Peter; USDA-ARS-DFRC, } \\
\text { Stock, Melanie; University of Wisconsin } \\
\text { Feyereisen, Gary; USDA-ARS, Soil and Water Management Research Unit } \\
\text { Arriaga, Francisco; University of Wisconsin, Deptartment of Soil Science } \\
\text { Good, Laura } \\
\text { Karthikeyan, K.G.; University of Wisconsin, }\end{array}$ \\
\hline Keywords: & manure, snowmelt, nutrients \\
\hline & \\
\hline
\end{tabular}


4 Peter A. Vadas*, Melanie N. Stock, Gary W. Feyereisen, Francisco J. Arriaga, Laura W. Good, 5

\section{Temperature and Manure Placement in a Snowpack Affect}

\section{Nutrient Release from Dairy Manure during Snowmelt}

P.A. Vadas, USDA-ARS, U.S. Dairy Forage Research Center, 1925 Linden Drive West,

Madison, WI 53706. M.N Stock, F.J. Arriaga, L.W. Good, and K.G. Karthikeyan, University of

Wisconsin-Madison. G.W. Feyereisen, USDA-ARS, Soil and Water Management Research Unit,

St Paul., MN. *Corresponding author: (peter.vadas@ars.usda.gov), 608-890-0069 (phone), 608890-0076 (fax).

3

4

15

6

7

8

9

0




\section{Abstract}

Agricultural nutrient management is an issue due to nitrogen $(\mathrm{N})$ and phosphorus $(\mathrm{P})$

26 losses from fields and water quality degradation. Better information is needed on the risk of

27 nutrient loss in runoff from dairy manure applied in winter. We investigated the effect of

28 temperature on nutrient release from liquid and semi-solid manure to water, and of manure

29 quantity and placement within a snowpack on nutrient release to melting snow. Temperature did

30 not affect manure $\mathrm{P}$ and ammonium-N $\left(\mathrm{NH}_{4}\right)$ release during water extraction. Manure $\mathrm{P}$ release,

31 but not $\mathrm{NH}_{4}-\mathrm{N}$ release, was significantly influenced by the water-to-manure solids extraction

32 ratio. During snowmelt, manure P release was not significantly affected by manure placement in

33 the snowpack, and the rate of $\mathrm{P}$ release decreased as application rate increased. Water extraction

34 data can reliably estimate P release from manure during snowmelt; however, snowmelt water

35 interaction with manure of greater solids content and subsequent $\mathrm{P}$ release appears incomplete

36 compared to liquid manures. Manure $\mathrm{NH}_{4}-\mathrm{N}$ released during snowmelt was statistically the same

37 regardless of application rate. For the semi-solid manure, $\mathrm{NH}_{4}-\mathrm{N}$ released during snowmelt

38 increased with the depth of snow covering it, most likely due to reduced $\mathrm{NH}_{3}$ volatilization. For

39 the liquid manure, there was no effect of manure placement within the snowpack on $\mathrm{NH}_{4}-\mathrm{N}$

40 released during snowmelt. Water extraction data can also reliably estimate manure $\mathrm{NH}_{4}-\mathrm{N}$

41 release during snowmelt as long as $\mathrm{NH}_{3}$ volatilization is accounted for with liquid manures for

42 all placements in a snowpack and semi-solid manures applied on top of snow. 
Agricultural nutrient management continues to be an important area of scientific research and policy development due to concerns over $\mathrm{N}$ and $\mathrm{P}$ losses in surface runoff from farm fields and subsequent water quality degradation (Carpenter et al., 1998; Parris, 2011). Research has consistently shown that surface manure application to fields without incorporation can be a

51 significant source of N and P loss (Daniel et al., 1998; Kleinman and Sharpley, 2003; Vadas et

52 al., 2007). In many northern U.S. states, as well as Canadian provinces and northern European

53 countries, winter application of dairy manure is common because it reduces the need for

54 expensive manure storage, allows time for manure spreading when there are fewer on-field

55 activities, and potentially reduces soil compaction from heavy equipment if soil is frozen

56 (Srinivasan et al., 2006). Because soils are frozen, winter-applied dairy manure is typically

57 surface applied and left unincorporated. This fact, combined with regular and significant runoff

58 from snowmelt and rain-on-snow events, has prompted many states to restrict winter spreading

59 of dairy manure (Srinivasan et al., 2006), including relatively new rules in Iowa

60 (http://www.iowadnr.gov/About-DNR/DNR-News-Releases/ArticleID/1096). However, there

61 has been relatively little research on nutrient loss from winter applied manure as support for

62 restrictions, especially compared to research on manure nutrient loss during non-winter periods

63 (see citations below).

The potential for manure nutrient runoff during winter is complex and can vary due to

65 infiltration, runoff, erosion, and nutrient cycling processes, all of which are sensitive to air

66 temperatures and frozen soil conditions. Nutrient loss may also vary with manure spreading

67 practices, especially relative to manure placement beneath or on top of snow and the effect of

68 manure on rates of snow melt (Kongoli and Bland, 2002). Detailed studies of soil and manure

69 interactions and the hydrological processes that affect nutrient transport under winter conditions 
70 are limited. Most studies have been observational with mixed results regarding the degree to

71 which winter manure application increases the risk of nutrient runoff relative to manure

72 application in other seasons. A majority of research was conducted before 1980 (Converse et al.,

73 1976; Steenhuis et al., 1981; Young and Mutchler, 1976; Young and Holt, 1977; Klausner et al.,

74 1976; Phillips et al., 1981). While there has been some more recent research (Hansen et al.,

75 2000; Komiskey et al., 2011; Lewis and Makarewicz, 2009; Owens et al., 2011; Ulen, 2003), it

76 was observational at the field-scale or larger, and did not provide data on liquid manures. The

77 review paper of Srinivasan et al. (2006) details the results of most of these studies. Only the

78 recent research of Williams et al. $(2011 ; 2012 b$, a) has investigated winter processes at the

79 controlled lab scale. Overall, a process-level understanding of nutrient cycling and transport

80 processes associated with winter manure application is lacking, especially for liquid manures.

81 Our goal is to improve the understanding and modeling of biochemical and physical

82 processes controlling frozen-soil and snowmelt infiltration, runoff, and nutrient loss from soil

83 and winter-applied dairy manure through a series of lab and field-plot scale experiments. Lab

84 experiments, such as the ones reported here, investigate specific processes under controlled

85 conditions at small scales rather than under variable weather at field scales, which combined can

86 make it difficult to identify relative importance of multiple processes. The specific objectives in

87 the current lab experiments were to 1) investigate if less $\mathrm{P}$ and $\mathrm{NH}_{4}$ are released from manure to

88 water due to low temperatures that would occur during snowmelt (as compared to rain events in

89 non-winter periods); 2) investigate the effect of dairy manure solids content, application amount,

90 and placement within a snowpack on $\mathrm{P}$ and $\mathrm{NH}_{4}$ release to melting snow; and 3) determine if

91 relationships from Objective 1 can reliably predict nutrient release from manure during snowmelt

92 in Objective 2. 
94 Materials and Methods

\section{Manure Extraction Experiments at Different Temperatures}

We collected three dairy manures from Holstein lactating cows: i) a liquid manure at the

97 University of Wisconsin cattle research center in Arlington, WI (Arlington liquid); ii) a semi-

98 solid manure at the USDA Dairy Forage Research Center (DFRC semi-solid) farm in Prairie du

99 Sac, WI; and iii) a semi-solid manure from a commercial farm in Minnesota (MN manure). The

100 Arlington liquid manure was from a storage lagoon and had a solids content of $4.6 \%$ as

101 determined gravimetrically after drying at $65^{\circ} \mathrm{C}$. Manure in the lagoon was from a barn flush

102 system where bedding sand had been separated by gravity settling. On a dry-weight basis, total $\mathrm{N}$

103 content was $77.6 \mathrm{~g} \mathrm{~kg}^{-1}$, and total P content was $11.0 \mathrm{~g} \mathrm{~kg}^{-1}$. The DFRC (12.6\% solids) and MN

104 (11.6\% solids) semi-solid manures were both collected from the floor of free-stall barns at the

105 point of mechanical consolidation. For the DFRC manure, dry-weight-basis total N content was

$10628.0 \mathrm{~g} \mathrm{~kg}^{-1}$, and total $\mathrm{P}$ content was $5.3 \mathrm{~g} \mathrm{~kg}^{-1}$. For the MN manure, dry-weight-basis total $\mathrm{N}$

107 content was $43.8 \mathrm{~g} \mathrm{~kg}^{-1}$, and total $\mathrm{P}$ content was $9.0 \% \mathrm{~g} \mathrm{~kg}^{-1}$. Manures were stored at $4{ }^{\circ} \mathrm{C}$ when

108 not in use.

109 We conducted a series of manure extractions with water at different temperatures to

110 investigate if cold temperatures that occur during snowmelt reduce nutrient release from manure

111 compared to warmer temperatures during non-winter rain events. We conducted all extractions in

112 triplicate. Our procedures followed those of Kleinman et al. (2002) and Vadas and Kleinman

113 (2006) where fresh manure was shaken with deionized water for $1 \mathrm{~h}$ at different extraction ratios

$114\left(\mathrm{~cm}^{3} \mathrm{~g}^{-1}\right.$, dry weight equivalent). Our extraction ratios included 50:1, 100:1, 250:1, and 500:1,

115 and temperatures included $22,15,10$, and $5^{\circ} \mathrm{C}$. The $\mathrm{MN}$ manure was also extracted at $1{ }^{\circ} \mathrm{C}$. For 
116 extractions, we weighed manure and water into separate flasks, placed them into a temperature-

117 controlled shaker and let them equilibrate to the desired temperature for at least $24 \mathrm{~h}$ without

118 shaking. We then combined the water and manure, shook the mixtures for $1 \mathrm{~h}$, and filtered them

119 through $0.45 \mu \mathrm{m}$ filters. We analyzed the filtered samples for dissolved reactive P (DRP)

120 colorimetrically (Murphy and Riley, 1962) on a spectrophotometer, and for $\mathrm{NH}_{4}-\mathrm{N}_{\text {and }} \mathrm{NO}_{3}-\mathrm{N}$

121 on a Lachat automated analyzer (Hach Company, Loveland, CO) using QuickChem Methods 12-

122 107-06-2-A (ammonium) and 12-107-04-1-B (nitrate). Throughout the experiments, $\mathrm{NO}_{3}-\mathrm{N}$

123 concentrations in manure extractions and snowmelt leachings (see below) were negligible, so we

124 do not present data for this $\mathrm{N}$ form.

126 Snowmelt Leaching Experiments

127 We designed these experiments to investigate nutrient release from manure to melting

128 snow water. This is the first step in understanding and modeling potential manure nutrient

129 transport in runoff. We therefore conducted experiments with snow and manure only, in the

130 absence of underlying soil. We used only the Arlington liquid manure and DFRC semi-solid

131 manure for these leaching experiments. We conducted experiments in triplicate using 15-cm

132 diameter funnels that had flat bottoms and a series of small drainage holes. We collected natural

133 snow and stored it frozen until use. We added snow and manure to funnels to achieve three rates

134 of manure, and three manure placements in a snowpack, which were below snow, between two

135 equivalent snow layers, and on top of snow. For the liquid manure, we added a snow equivalent

136 of $1400 \mathrm{~mL}$ of water and manure at three wet-weight amounts of 98, 197 and $394 \mathrm{~g}$. This

137 achieved a relatively wide range of liquid (including snow and manure liquid) to manure dry

138 matter ratios of 96,174 , and $331 \mathrm{~cm}^{3} \mathrm{~g}^{-1}$ (Table 4). For the semi-solid manure, we added a snow 
139 equivalent of $1250 \mathrm{~mL}$ of water and manure at wet-weight rates of 32, 68 and $136 \mathrm{~g}$. This

140 achieved liquid to manure dry matter ratios of 74,144 , and $315 \mathrm{~cm}^{3} \mathrm{~g}^{-1}$ (Table 4). For each

141 funnel, we froze a piece of acid-washed, nylon screen in $30 \mathrm{~mL}$ of deionized water and placed

142 the screen in the funnel before adding any manure or snow. This prevented any immediate loss

143 of manure through funnels before snowmelt began. When assembled, we placed all funnels in a

144 cold room at approximately $4^{\circ} \mathrm{C}$ and allowed snow to melt, which took between 44 to $58 \mathrm{~h}$.

145 During melt, we collected all leachate in increments of 250-300 mL. We filtered and analyzed all 146 samples for $\mathrm{NH}_{4}$ and $\mathrm{P}$ as described above.

\section{Statistical Analysis}

149 We used the general linear model of SAS (SAS Version 9.4) along with Tukey's mean 150 separation to conducted a statistical analysis of results. For the water extraction experiment, 151 variables of DRP and $\mathrm{NH}_{4}-\mathrm{N}$, total treatment sums of squares (SS) for the fixed effects in the 152 ANOVA were partitioned into partial SS associated with the three manure types, four extraction 153 ratios, five temperatures, and all their two-way and three-way treatment interactions. We used 154 partial SS to determine the percentage of total DRP and $\mathrm{NH}_{4}-\mathrm{N}$ associated with each treatment 155 effect or treatment interaction. Treatment differences discussed in the text were significant at the 1560.05 probability level. We conducted a similar statistical analysis for the funnel leaching 157 experiments, where fixed effects were the two manure types, three application rates, three 158 placements in the snowpack, and all their two-way and three-way treatment interactions.

\section{Results and Discussion}

161 Manure Extraction Experiments 
163 extractable $\mathrm{P}$ (WEP) to be consistent with terminology in previous studies on manure $\mathrm{P}$

164 extractability (Kleinman et al., 2002; Vadas and Kleinman, 2006; Kleinman et al., 2005). Figure

1651 shows results for manure WEP ( $\mathrm{mg} \mathrm{kg}^{-1}$ dry weight equivalent) for the three dairy manures as a

166 function of extraction ratio and temperature. Statistical analysis indicated that only extraction

167 ratio had a significant effect on WEP, and explained $60 \%$ of its variability (Table 1 ). This was

168 true for WEP expressed on a mass basis $\left(\mathrm{mg} \mathrm{kg}^{-1}\right.$ dry weight equivalent) or as a percent of total $\mathrm{P}$

169 in the manure. Manure type and the manure by extraction ratio interaction each explained $16 \%$ of

170 WEP variability, but were not statistically significant. Across all three manures, temperature did

171 not significantly affect WEP, even though there was less WEP from the Arlington liquid manure

172 as temperature decreased from $22^{\circ} \mathrm{C}$ to $10^{\circ} \mathrm{C}$, with no further decrease less than $10^{\circ} \mathrm{C}$. This

173 suggests cold temperatures do not affect P release from manure substantially enough that models

174 need to account for the variable (Bechmann et al., 2005).

175 Figure 2 shows results for water extractable manure $\mathrm{NH}_{4}-\mathrm{N}$ as a function of extraction

176 ratio and temperature. Statistical analysis showed that only manure type had a significant effect

177 on extractable $\mathrm{NH}_{4}-\mathrm{N}$, and explained $98 \%$ of the data variability (Table 1). There was greater

178 extractable $\mathrm{NH}_{4}-\mathrm{N}$ for the liquid manure than the semi-solid manures, which did not differ from

179 each other. While this statistical effect of manure type was true on a mass basis $\left(\mathrm{mg} \mathrm{kg}^{-1}\right.$ dry

180 weight equivalent), it was not true for $\mathrm{NH}_{4}-\mathrm{N}$ expressed as a percent of total $\mathrm{N}$ in manure. Since

181 total $\mathrm{N}$ content varied from 28.0 to $77.6 \mathrm{~g} \mathrm{~kg}^{-1}$ across manures, comparing data as a percent of

182 total $\mathrm{N}$ may be more equitable. Given that, Figure 2 shows that manure $\mathrm{NH}_{4}-\mathrm{N}$ release to water

183 was fairly rapid and complete regardless of temperature, extraction ratio, or manure type. Good

184 (2002) also observed no effect of extraction ratio on manure $\mathrm{NH}_{4}-\mathrm{N}$ release. This suggests that 
185 models do not need to account for these variables when estimating $\mathrm{NH}_{4}-\mathrm{N}$ release from manure

186 during snowmelt.

188 Phosphorus Dynamics during Snowmelt Leaching

In all experiments, DRP concentrations in snowmelt water in the absence of manure were

190 less than $0.05 \mathrm{mg} \mathrm{L}^{-1}$. Results in Figures 3 and 4 show that DRP concentrations in incremental

191 leachate for both the liquid manure and the DFRC semi-solid manure increased as snowmelt

192 progressed. These data are consistent with our lab extraction data that DRP release is a function

193 of how much water interacts with manure. Thus during snowmelt when liquid water interaction

194 with manure is gradual, DRP release is more likely to increase as snowmelt proceeds and leads

195 to interaction with more water (Kleinman et al., 2002).

Table 3 presents cumulative manure DRP released (mg) for both the liquid and semi-

197 solid manures over the entire snowmelt period. Statistical analysis in Table 2 shows that on a

198 mass basis (mg) there was no effect of manure type, placement in the snowpack, or application

199 rate on cumulative DRP released. However, when expressed as a percent of total manure P

200 applied, there was an effect of application rate on cumulative DRP released (Table 2). Thus, the

201 proportion of applied manure total $\mathrm{P}$ that leached decreased as application rate increased. The

202 three manure application rates during snowmelt represented about 50, 100, and $200 \mathrm{mg}$ applied

203 total $\mathrm{P}$ for the liquid manure and 21, 45, and $91 \mathrm{mg}$ for the DFRC semi-solid manure for the

204 high, medium, and low application rates, respectively (Table 4). Therefore, the amount of

205 manure DRP leached during snowmelt was about 5, 9, and 17\% of total P applied for the high,

206 medium, and low application rates for both manures. These results are consistent with our lab

207 extraction data showing that $\mathrm{P}$ leaching is a function of the water:solids extraction ratio and that 
208 a greater percentage of manure P is released at greater ratios (Vadas et al., 2004; Vadas et al., 209 2005). In the snowmelt leaching experiments, as the amount of applied manure increased, the 210 ratio of snow water to manure solids (equivalent to extraction ratio during the water extraction 211 experiments) decreased, and thus the percentage of applied P that was released also decreased.

212 There was no significant effect of manure placement within the snowpack on cumulative

213 DRP released (Tables 2 and 3). Young and Mutchler (1976) suggested that manure applied

214 below snow may have greater potential to interact with liquid snowmelt water and lose more

215 nutrients in runoff. However, in controlled laboratory experiments using soil boxes, Williams et

216 al. (2011) found less P loss in runoff from manure applied below snow compared to on top of or

217 within snow and suggested this was because manure remained frozen below snow (due to

218 influence of frozen soil) and was less susceptible to P loss. Phosphorus loss in runoff was the

219 same for manure applied on top of or within snow. Our experiments did not have underlying soil

220 and are not strictly comparable to these runoff studies. However, our data are consistent with

221 those of Williams et al. (2011) for manure applied on top of or within snow, and suggest that

222 snowmelt water interaction with manure and release of $\mathrm{P}$, and thus potential $\mathrm{P}$ loss in snowmelt

223 runoff, is functionally similar regardless of where manure is in the snowpack. Instead, site

224 snowmelt dynamics, degree of snowmelt water interaction with manure, and runoff hydrology

225 are likely more dominant mechanisms controlling manure P release during snowmelt and

226 potential loss in runoff than manure placement in the snowpack (Kongoli and Bland, 2002). This

227 suggests nutrient runoff models do not need to account for manure placement in a snowpack for 228 P. 
Vadas et al. $(2004 ; 2005)$ showed that manure water extraction data such as those in

230 Figure 1 can be used to reliably estimate how much DRP is leached from manure during a rain

231 event. The equation used in that research to estimate DRP leached from manure by rain was:

233 DRP release $=[1.2 \mathrm{~W} /(\mathrm{W}+73.1)]($ manure $\mathrm{WEP})$

where $\mathrm{W}$ is the water to manure extraction ratio $\left(\mathrm{cm}^{3} \mathrm{~g}^{-1}\right)$, WEP is the manure DRP that is

236 extracted (in mass units such as $\mathrm{mg}$ or $\mathrm{mg} \mathrm{kg}^{-1}$ ) at a $\mathrm{W}$ of 250:1 over $1 \mathrm{~h}$, and DRP release is in

237 the same units as WEP. Equation [1] fit well to the lab extraction data for the DFRC semi-solid

238 manure in Figure $1\left(r^{2}=0.70\right)$, so we applied Eq. [1] to see if it could reliably estimate DRP

239 release from manure during our snowmelt leaching experiments. For the semi-solid manure,

240 manure solids application rates and $\mathrm{W}$ values during snowmelt leaching are in Table 4. We

241 estimated a manure WEP of $1560 \mathrm{mg} \mathrm{kg}^{-1}$ based on data at the 250:1 extraction ratio in Figure 1.

242 Applying Eq. [1] resulted in estimated DRP release amounts of 16.1, 10.6, and 6.1 mg for the

243 high, medium, and low application rates, respectively (Table 4). Corresponding measured rates

244 as averaged across manure placements in snow were 4.7, 4.5, and $3.7 \mathrm{mg}$ for high, medium, and

245 low application rates (Table 3).

246 Clearly, less DRP was leached from the semi-solid manure during snowmelt than Eq. [1]

247 would estimate. If we assume that the basic leaching processes represented by Eq. [1] still

248 applied, underestimated DRP leaching suggests that not all the snowmelt water interacted with

249 manure and that $\mathrm{W}$ as applied in Eq. [1] should have been less. In fact, the degree to which

250 measured DRP release was less than that estimated by Eq. [1] was consistent. We calculated that

251 if only $20 \%$ of snowmelt water actually interacted with manure, then Eq. [1] W values would be 
25215,29 , and $63 \mathrm{~cm}^{3} \mathrm{~g}^{-1}$; and corresponding estimated DRP release would be 4.7, 4.5, and $3.5 \mathrm{mg}$,

253 for the high, medium, and low application rates, respectively. These estimated DRP release

254 values are similar to measured values (Table 3).

255 Overall, our snowmelt leaching and water extraction data results suggest that for semi-

256 solid manures Eq. [1] can be used in models to estimate DRP release from manure during

257 snowmelt, and that DRP release is not a function of temperature or manure placement in a

258 snowpack during snowmelt. However, the amount of snowmelt water that actually interacts with

259 the manure and subsequent DRP release is significantly less compared to water interaction with

260 manure during a rain event. During modeling research using Eq. [1] to simulate P loss in runoff

261 from winter applied manure, Vadas et al. (2017) found that field scale runoff data also indicated

262 incomplete interaction of snowmelt water with solid beef manure. Clearly, this possibility of

263 incomplete snowmelt water interaction with solid manure and reduced DRP release deserves

264 further investigation, especially as we could find no literature on this topic.

265 For the Arlington liquid manure, Eq. [1] did not effectively describe the lab WEP

266 extraction data in Figure $1\left(r^{2}=0.05\right)$. The reason for this is unknown, but could be related to

267 manure P mineralogy, which can be a function of animal diet or bedding material (Pagliari,

268 2011). The liquid manure WEP extraction data instead exhibited a linear increase in manure

269 WEP with W, while Eq. [1] is nonlinear. Therefore, we used data from Figure 1 (as averaged

270 across all temperatures) to represent DRP release from the liquid manure as:

271

272 DRP release $=(0.005 \mathrm{~W}-0.253)($ manure WEP $) \quad \mathrm{r}^{2}=0.96$ 
274 For the liquid manure, manure solids application amounts and $\mathrm{W}$ values are in Table 4 . We

275 estimated a manure WEP of $1840 \mathrm{mg} \mathrm{kg}^{-1}$ based on data at the $250: 1$ extraction ratio in Figure 1.

276 Applying Eq. [2] resulted in manure DRP release amounts of 8.4, 10.3 and $7.7 \mathrm{mg}$ for the high,

277 medium, and low application rates, respectively (Table 4). Corresponding measured rates were

$2787.8,8.0$, and $8.6 \mathrm{mg}$ for the high, medium, and low application rates (Table 3). Similar to the

279 DFRC semi-solid manure, these liquid manure results suggest that lab water extraction data can

280 be used to estimate DRP release from manure during snowmelt, without considering temperature

281 or manure placement in a snowpack during snowmelt. Data also demonstrate that when

282 estimating DRP release from a liquid manure during snowmelt, incomplete snowmelt water

283 interaction with manure does not need to be considered. This may be because liquid manure is

284 more evenly distributed and absorbed into the snowpack than a semi-solid manure, and thus has

285 a potential for greater snowmelt interaction. As before, this possibility of more complete

286 snowmelt interaction with liquid manure but incomplete snowmelt water interaction with more

287 solid manure deserves further investigation.

289 Nitrogen Dynamics during Snowmelt Leaching

290 In all leaching experiments, $\mathrm{NH}_{4}-\mathrm{N}$ concentrations in snow water without manure were

291 less than $0.30 \mathrm{mg} \mathrm{L}^{-1}$. Results in Figures 3 and 4 show that $\mathrm{NH}_{4}-\mathrm{N}$ concentrations in incremental

292 leachate water from both the liquid and semi-solid manures decreased as snowmelt progressed.

293 These data are consistent with our lab extractions that showed $\mathrm{NH}_{4}-\mathrm{N}$ release is not a function of

294 how much water interacts with manure. Thus during snowmelt, $\mathrm{NH}_{4}-\mathrm{N}$ release would be

295 expected to be rapid even with only low amounts of snowmelt water (first flush phenomenon). 
Statistical analysis in Table 2 shows that only manure type had a significant effect on 297 mass (mg) of cumulative $\mathrm{NH}_{4}-\mathrm{N}$ leached during snowmelt (Table 3). However, when $\mathrm{NH}_{4}-\mathrm{N}$ 298 release was expressed as a function of total $\mathrm{N}$ applied in manure, no treatment variables had a 299 significant effect on $\mathrm{NH}_{4}-\mathrm{N}$ leached (Table 2). Thus, a similar percentage of applied total $\mathrm{N}$ 300 leached from manure regardless of application rate and thus snow water:manure solids ratio. For 301 both manures, an average of $19.2 \%$ (s.d. of $2.3 \%$ ) of applied manure total $\mathrm{N}$ was leached. For the semi-solid manure, although placement in the snowpack was not a significant

303 factor (Table 2), the amount of $\mathrm{NH}_{4}-\mathrm{N}$ leached during snowmelt consistently increased with the 304 depth of snow covering it (Table 3). This is most likely because manure applied on top of snow, 305 and even between snow layers, had longer direct exposure to the air above it, had greater $\mathrm{NH}_{3}$ 306 volatilization, and thus had less $\mathrm{NH}_{4}-\mathrm{N}$ available for leaching loss (Williams et al., 2011; Lauer 307 et al., 1976). Steenhuis et al. (1979) observed about $35 \%$ greater $\mathrm{NH}_{3}$ volatilization from a dairy 308 manure (16\% solids) placed on top of a snow pack compared to below a $10 \mathrm{~cm}$ snowpack over 309 four days. Similarly, we observed about $30 \%$ more $\mathrm{NH}_{4}-\mathrm{N}$ in leachate from our semi-solid 310 manure when manure was below the snowpack compared to on top. An average of $20.6 \%$ (s.d. of $3111.7 \%$ ), $18.6 \%$ (s.d. of $1.5 \%$ ), and $13.5 \%$ (s.d. of $0.7 \%$ ) of applied manure total $\mathrm{N}$ was leached as

$312 \mathrm{NH}_{4}-\mathrm{N}$ for the manure below, in between, and on top of snow, respectively. For the liquid

313 manure at a given manure application rate, there was no trend of manure placement within the

314 snowpack on $\mathrm{NH}_{4}-\mathrm{N}$ leached during snowmelt (Table 3). An average of $20.9 \%$ (s.d. of $2.3 \%$ ) of 315 manure total $\mathrm{N}$ was leached as $\mathrm{NH}_{4}-\mathrm{N}$. Therefore, our data suggest that $\mathrm{NH}_{3}$ volatilization may 316 not vary as a function of placement in a snowpack for liquid manure. 
318 release from manure during snowmelt. Combining the data from all three manures in Figure 2,

319 we developed the equation below (similar to Eqs. [1] and [2]):

323 Solids application rates and $\mathrm{W}$ values during snowmelt leaching are in Table 4 . We estimated

324 manure $\mathrm{NH}_{4}-\mathrm{N}$ from maximum amounts extracted during water extractions (Figure 2). Applying

325 Eq. [3] for the semi-solid manure resulted in predicted $\mathrm{NH}_{4}-\mathrm{N}$ release of 86.3, 44.7, and $22.8 \mathrm{mg}$

326 for the high, medium, and low application rates, respectively (Table 4). Corresponding average

327 measured $\mathrm{NH}_{4}-\mathrm{N}$ release rates when manure was applied below or between snow layers were 328 88.6, 45.7, and $24.0 \mathrm{mg}$ (Table 3). Therefore, Eq. [3] reliably estimated manure $\mathrm{NH}_{4}-\mathrm{N}$ release

329 for these two manure placements. However, corresponding measured $\mathrm{NH}_{4}-\mathrm{N}$ release rates when

330 manure was applied on top of snow was 64.3, 30.7, and $15.9 \mathrm{mg}$ (Table 3). Therefore, Eq. [3]

331 over-estimated manure $\mathrm{NH}_{4}-\mathrm{N}$ release for this manure placement. It is reasonable to assume that

332 overprediction is due to unaccounted for $\mathrm{NH}_{3}$ volatilization from manure applied on top of snow.

333 In fact, if we assume a $\mathrm{NH}_{3}$ volatilization rate of $35 \%$ for manure applied on top of snow, as

334 reported by Steenhuis et al. (1979) (i.e., 35\% less manure $\mathrm{NH}_{4}-\mathrm{N}$ available to leach), predicted

$335 \mathrm{NH}_{4}-\mathrm{N}$ release in snowmelt would be $56.1,29.0$, and $14.8 \mathrm{mg}$, which is close to measured

336 values. Converse to $\mathrm{P}$, these data also demonstrate that when estimating manure $\mathrm{NH}_{4}-\mathrm{N}$ release

337 from a semi-solid manure during snowmelt, incomplete snowmelt water interaction with manure

338 does not need to be considered. This may be because $\mathrm{NH}_{4}-\mathrm{N}$ release is much less sensitive to the 339 amount of water that interacts with manure (Fig. 2). 
For the liquid manure, manure solids application rates and $\mathrm{W}$ values are in Table 4.

341 Applying Eq. [3] resulted in predicted $\mathrm{NH}_{4}-\mathrm{N}$ release amounts of 479.0, 239.5, and $112.7 \mathrm{mg}$ for

342 the high, medium, and low application rates, respectively (Table 4). Corresponding measured

$343 \mathrm{NH}_{4}-\mathrm{N}$ release rates were clearly much less at $266.7,150.1$, and $79.5 \mathrm{mg}$ (Table 3 ). If we

344 attribute overprediction to $\mathrm{NH}_{3}$ volatilization from applied manure, a volatilization rate of $35 \%$

345 of applied manure $\mathrm{NH}_{4}-\mathrm{N}$ would result in predicted $\mathrm{NH}_{4}-\mathrm{N}$ release during snowmelt of 282.2,

346146.6 , and $78.9 \mathrm{mg}$, which agreed well with measured rates. Overall, our data suggest that water

347 extraction data can be used to reliably estimate manure $\mathrm{NH}_{4}-\mathrm{N}$ release during snowmelt without

348 having to consider temperature or $\mathrm{NH}_{3}$ volatilization if a semi-solid to solid manure is covered

349 by snow. However, $\mathrm{NH}_{3}$ volatilization needs to be accounted for with liquid manures at all

350 placements in a snowpack and a semi-solid manure applied on top of snow.

352 Conclusions

353 Our lab-scale experiments suggest that temperature may not significantly influence

354 manure WEP and $\mathrm{NH}_{4}-\mathrm{N}$ release to water. Also, manure WEP release, but not $\mathrm{NH}_{4}-\mathrm{N}$ release, to

355 water will be influenced by the water-to-manure solids ratio. Manure placement within a

356 snowpack may not significantly influence snowmelt interaction with manure and leaching of

357 DRP. For semi-solid manures, the amount of $\mathrm{NH}_{4}-\mathrm{N}$ leached during snowmelt can increase with 358 the depth of snow covering it. This is mostly likely because manure applied on top of snow, and

359 even between snow layers, has greater $\mathrm{NH}_{3}$ volatilization and thus less $\mathrm{NH}_{4}-\mathrm{N}$ available for

360 leaching loss. For liquid manures, $\mathrm{NH}_{3}$ volatilization may not vary as a function of placement in

361 a snowpack, but liquid manures applied to snow will have greater $\mathrm{NH}_{3}$ volatilization than more

362 solid manures unless the solid manures are applied on top of snow and have significant $\mathrm{NH}_{3}$ 
363 volatilization. Finally, lab water extractions can be used to reliably estimate manure $\mathrm{NH}_{4}-\mathrm{N}$

364 release during snowmelt, but variations in $\mathrm{NH}_{3}$ volatilization need to be accounted for with

365 liquid manures at all placements in a snowpack and a semi-solid manure applied on top of snow.

366 Lab water extractions can also be used to estimate DRP release from manure during snowmelt;

367 but for semi-solid to solid manures, the amount of snowmelt water that actually interacts with the

368 manure and subsequent WEP release is significantly less compared to water interaction with

369 manure during a rain event. The same is not true for liquid manures applied to snow. This may

370 be because liquid manure is more evenly distributed and absorbed into a snowpack than a semi-

371 solid manure, and thus has a greater potential for complete snowmelt interaction. This possibility

372 of more complete snowmelt interaction with liquid manures but incomplete snowmelt water

373 interaction with more solid manure during DRP release deserves further investigation, especially

374 as a function of a range of manure solids content. Overall, our data will help improve simulation

375 models that can be applied to explore the management and environmental implications of winter

376 manure spreading and variable winter runoff conditions.

\section{References}

Bechmann, M.E., P.J.A. Kleinman, A.N. Sharpley, and L.S. Saporito. 2005. Freeze-thaw effects on phosphorus loss in runoff froin manured and catch-cropped soils. J. Environ. Qual. 34:2301-2309.

Carpenter, S.R., N.F. Caraco, D.L. Correll, R.W. Howarth, A.N. Sharpley, and V.H. Smith. 1998. Nonpoint pollution of surface waters with phosphorus and nitrogen. Ecol. Appl. 8:559-568.

Converse, J.C., G.D. Bubenzer, and W.H. Paulson. 1976. Nutrient Losses in Surface Runoff from Winter Spread Manure. Trans. ASAE 19:517-519.

Daniel, T.C., A.N. Sharpley, and J.L. Lemunyon. 1998. Agricultural phosphorus and eutrophication: A symposium overview. J. Environ. Qual. 27:251-257.

Good, L.W. 2002. Mechanisms controlling phosphorus loss to water from animal manures and manure-amended soils. Ph.D. diss., Univ. Wisconsin, Madison.

Hansen, N.C., S.C. Gupta, and J.F. Moncrief. 2000. Snowmelt runoff, sediment, and phosphorus losses under three different tillage systems. Soil Till Res 57:93-100. 
Klausner, S.D., P.J. Zwerman, and D.F. Ellis. 1976. Nitrogen and Phosphorus Losses from Winter Disposal of Dairy Manure. J. Environ. Qual. 5:47-49.

Kleinman, P.J.A., and A.N. Sharpley. 2003. Effect of broadcast manure on runoff phosphorus concentrations over successive rainfall events. J. Environ. Qual. 32:1072-1081.

Kleinman, P.J.A., A.N. Sharpley, A.M. Wolf, D.B. Beegle, and P.A. Moore. 2002. Measuring water-extractable phosphorus in manure as an indicator of phosphorus in runoff. Soil Sci. Soc. Am. J. 66:2009-2015.

Kleinman, P.J.A., A.M. Wolf, A.N. Sharpley, D.B. Beegle, and L.S. Saporito. 2005. Survey of water-extractable phosphorus in livestock manures. Soil Sci. Soc. Am. J. 69:701-708.

Komiskey, M.J., T.D. Stuntebeck, D.R. Frame, and F.W. Madison. 2011. Nutrients and sediment in frozen-ground runoff from no-till fields receiving liquid-dairy and solid-beef manures. J. Soil Water Conserv. 66:303-312.

Kongoli, C.E., and W.L. Bland. 2002. Influence of manure application on surface energy and snow cover: Field experiments. J. Environ. Qual. 31:1166-1173.

Lauer, D.A., D.R. Bouldin, and S.D. Klausner. 1976. Ammonia Volatilization from Dairy Manure Spread on Soil Surface. J. Environ. Qual. 5:134-141.

Lewis, T.W., and J.C. Makarewicz. 2009. Winter application of manure on an agricultural watershed and its impact on downstream nutrient fluxes. J Great Lakes Res 35:43-49.

Murphy, J., and J.P. Riley. 1962. A Modified Single Solution Method for Determination of Phosphate in Natural Waters. Anal. Chim. Acta 27:31-36.

Owens, L.B., J.V. Bonta, M.J. Shipitalo, and S. Rogers. 2011. Effects of Winter Manure Application in Ohio on the Quality of Surface Runoff. J. Environ. Qual. 40:153-165.

Pagliari, P.H. 2011. Investigation of inorganic and organic phosphorus in animal manure and their effects on soil test phosphorus. Ph.D. diss., Univ. Wisconsin, Madison.

Parris, K. 2011. Impact of Agriculture on Water Pollution in OECD Countries: Recent Trends and Future Prospects. Int J Water Resour D 27:33-52.

Phillips, P.A., J.L.B. Culley, F.R. Hore, and N.K. Patni. 1981. Pollution Potential and Corn Yields from Selected Rates and Timing of Liquid Manure Applications. Trans. ASAE 24:139-144.

Srinivasan, M.S., R.B. Bryant, M.P. Callahan, and J.L. Weld. 2006. Manure management and nutrient loss under winter conditions: A literature review. J. Soil Water Conserv. 61:200209.

Steenhuis, T.S., G.D. Bubenzer, and J.C. Converse. 1979. Ammonia Volatilization of Winter Spread Manure. Trans. ASAE 22:152-\&.

Steenhuis, T.S., G.D. Bubenzer, J.C. Converse, and M.F. Walter. 1981. Winter-Spread Manure Nitrogen Loss. Trans. ASAE 24:436-442.

Ulen, B. 2003. Concentrations and transport of different forms of phosphorus during snowmelt runoff from an illite clay soil. Hydrological Processes 17:747-758.

Vadas, P.A., L.W. Good, W.E. Jokela, K.G. Karthikeyan, F.J. Arriaga, and M. Stock. 2017. Quantifying the impact of seasonal and short-term manure application decisions on phosphorus loss in surface runoff. J. Envrion. Qual. 46:doi:10.2134/jeq2016.2106.0220.

Vadas, P.A., B.E. Haggard, and W.J. Gburek. 2005. Predicting dissolved phosphorus in runoff from manured field plots. J. Environ. Qual. 34:1347-1353.

Vadas, P.A., R.D. Harmel, and P.J.A. Kleinman. 2007. Transformations of soil and manure phosphorus after surface application of manure to field plots. Nutr. Cycl. Agroeco. 77:8399. 
Vadas, P.A., and P.J.A. Kleinman. 2006. Effect of methodology in estimating and interpreting water-extractable phosohorus in animal manures. J. Environ. Qual. 35:1151-1159.

Vadas, P.A., P.J.A. Kleinman, and A.N. Sharpley. 2004. A simple method to predict dissolved phosphorus in runoff from surface-applied manures. J. Environ. Qual. 33:749-756.

Williams, M.R., G.W. Feyereisen, D.B. Beegle, and R.D. Shannon. 2012a. Soil Temperature Regulates Nitrogen Loss from Lysimeters Following Fall and Winter Manure Application. Trans. ASABE 55:861-870.

Williams, M.R., G.W. Feyereisen, D.B. Beegle, and R.D. Shannon. 2012b. Soil Temperature Regulates Phosphorus Loss from Lysimeters Following Fall and Winter Manure Application. Trans. ASABE 55:871-880.

Williams, M.R., G.W. Feyereisen, D.B. Beegle, R.D. Shannon, G.J. Folmar, and R.B. Bryant. 2011. Manure Application under Winter Conditions: Nutrient Runoff and Leaching Losses. Trans. ASABE 54:891-899.

Young, R.A., and R.F. Holt. 1977. Winter-Applied Manure - Effects on Annual Runoff, Erosion, and Nutrient Movement. J. Soil Water Conserv. 32:219-222.

Young, R.A., and C.K. Mutchler. 1976. Pollution Potential of Manure Spread on Frozen Ground.

(1)

(

(

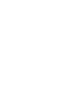

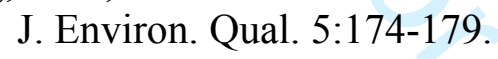
J. Environ. Qual. 5:174-179. 
473 Figure Captions

474

475 Figure 1. Manure WEP release for the Arlington liquid dairy manure and the DFRC and MN

476 semi-solid dairy manures during water extraction experiments as a function of extraction

477 temperature and extraction ratio (water to manure solids, $\mathrm{cm}^{3} \mathrm{~g}^{-1}$ ). Bars indicate the standard

478 deviation of the means.

479

480 Figure 2. Manure $\mathrm{NH}_{4}-\mathrm{N}$ release for the Arlington liquid dairy manure and the DFRC and MN

481 semi-solid dairy manures during water extraction experiments as a function of extraction

482 temperature and extraction ratio (water to manure solids, $\mathrm{cm}^{3} \mathrm{~g}^{-1}$ ). Bars indicate the standard

483 deviation of the means.

484

485 Figure 3. Change in dissolved $\mathrm{P}$ and $\mathrm{NH}_{4}-\mathrm{N}$ concentrations in snowmelt water with increasing

486 leachate volume during snowmelt leaching experiments with the Arlington liquid dairy manure

487 applied at three different rates. Data for a given rate are averaged across manure placements in

488 the snowpack. Bars indicate the standard deviation of the means.

490 Figure 4. Change in dissolved $\mathrm{P}$ and $\mathrm{NH}_{4}-\mathrm{N}$ concentrations in snowmelt water with increasing

491 leachate volume during snowmelt leaching experiments with the DFRC semi-solid dairy manure

492 applied at three different rates. Data for a given rate are averaged across manure placements in

493 the snowpack. Bars indicate the standard deviation of the means. 
495 Table 1. ANOVA for effects of manure, extraction ratio, and temperature on manure WEP and $\mathrm{NH}_{4}-\mathrm{N}_{\text {extracted during water }}$

496 extraction experiments. Data are presented for concentrations $\left(\mathrm{mg} \mathrm{kg}^{-1}\right)$ as well percent of total $\mathrm{P}$ or total $\mathrm{N}$ in manure.

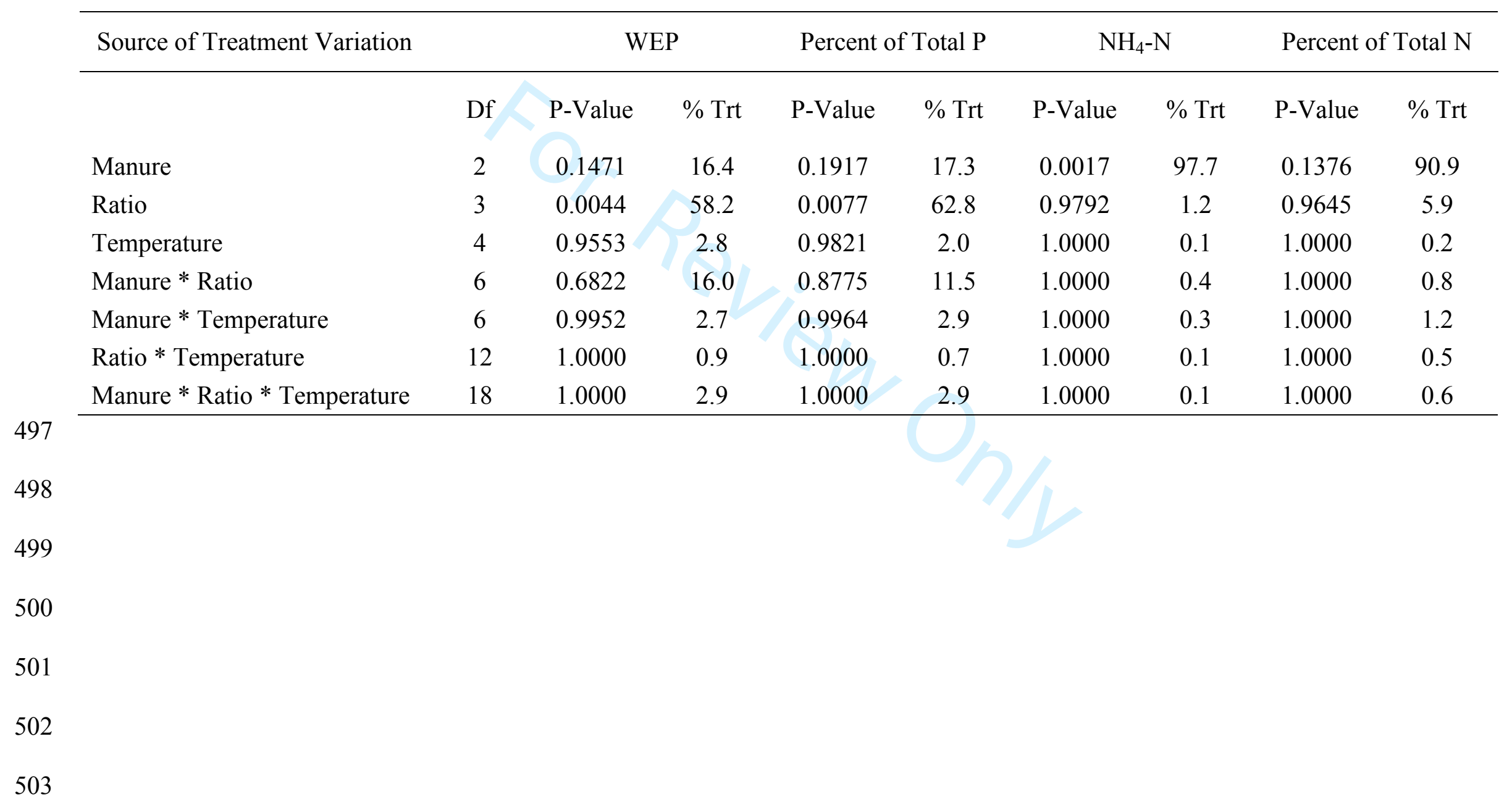


505 Table 2. ANOVA for effects of manure, extraction ratio, and temperature on manure DRP and $\mathrm{NH}_{4}-\mathrm{N}_{\text {leached during snowmelt }}$

506 leaching experiments. Data are presented for mass (mg) as well percent of total P or total $\mathrm{N}$ applied to funnels as manure.

\begin{tabular}{lccccccccc}
\hline \multicolumn{1}{c}{$\begin{array}{c}\text { Source of Treatment } \\
\text { Variation }\end{array}$} & & \multicolumn{2}{c}{ DRP } & & Percent of Total P & & NH H $^{-N}$ & & Percent of Total N \\
\hline & Df & P-Value & \% Trt & P-Value & \% Trt & P-Value & \% Trt & P-Value & \% Trt \\
Manure & 1 & 0.1006 & 76.7 & 0.6992 & 1.8 & 0.0254 & 53.0 & 0.5713 & 31.1 \\
Placement & 2 & 0.9632 & 1.9 & 0.9981 & 0.0 & 0.9857 & 0.3 & 0.8993 & 19.9 \\
Rate & 2 & 0.9928 & 0.4 & 0.0423 & 87.0 & 0.1710 & 34.8 & 0.9286 & 13.9 \\
Manure * Placement & 2 & 0.8219 & 10.2 & 0.7860 & 5.6 & 0.9903 & 0.2 & 0.9166 & 16.4 \\
Manure * Rate & 2 & 0.9473 & 2.8 & 0.9804 & 0.5 & 0.5693 & 10.4 & 0.9896 & 2.0 \\
Placement * Rate & 4 & 0.9991 & 2.1 & 0.9999 & 0.3 & 0.9993 & 0.6 & 0.9992 & 7.4 \\
Manure * Placement * Rate & 4 & 0.9931 & 6.0 & 0.9787 & 4.9 & 0.9989 & 0.8 & 0.9986 & 9.4 \\
\hline
\end{tabular}

507

508

509

510

511 
513 Table 3. Cumulative manure DRP and $\mathrm{NH}_{4}-\mathrm{N}$ release $(\mathrm{mg})$ for the Arlington Liquid and DFRC semi-solid dairy manures during

514 snowmelt experiments as a function of manure application rate (Low, Medium, High) and manure placement within a snowpack

515 (under snow, between snow layers, and on top of snow). Values in parentheses are DRP and $\mathrm{NH}_{4}-\mathrm{N}^{2}$ release expressed as percentages

516 of total $\mathrm{P}$ and total $\mathrm{N}$ applied as manure.

517

\begin{tabular}{|c|c|c|c|c|c|c|}
\hline Rate & Under & Between & Top & Under & Between & Top \\
\hline & & DRP & & & $\mathrm{NH}_{4}-\mathrm{N}$ & \\
\hline & $\mathrm{mg}$ & $\mathrm{mg}$ & $\mathrm{mg}$ & $\mathrm{mg}$ & $\mathrm{mg}$ & $\mathrm{mg}$ \\
\hline & & & $\begin{array}{l}\text { Liquid } \\
\text { Manure }\end{array}$ & & & \\
\hline Low & $6.5(13.0)$ & $9.0(18.0)$ & $10.2(20.4)$ & $74.2(21.1)$ & $89.6(25.5)$ & $74.8(21.3)$ \\
\hline Medium & $6.6(6.6)$ & $9.0(9.0)$ & $8.4(8.4)$ & $145.6(20.7$ & $164.5(23.4)$ & $140.1(19.9)$ \\
\hline \multirow[t]{2}{*}{ High } & $7.0(3.5)$ & $9.2(4.6)$ & $7.1(3.6)$ & 279.8 (19.9) & $260.7(18.5)$ & $259.6(18.9)$ \\
\hline & & & $\begin{array}{c}\text { Semi-solid } \\
\text { Manure }\end{array}$ & & & \\
\hline Low & $4.7(22.4)$ & $3.4(16.2)$ & $2.8(13.3)$ & $25.1(22.4)$ & $22.8(20.4)$ & $15.9(14.2)$ \\
\hline Medium & $5.4(12.0)$ & $3.8(8.4)$ & $4.3(9.6)$ & 49.7 (20.8) & $41.8(17.5)$ & $30.7(12.8)$ \\
\hline High & $5.2(5.7)$ & $4.3(4.7)$ & $4.6(5.1)$ & 90.5 (18.9) & $86.7(18.1)$ & $64.3(13.4)$ \\
\hline
\end{tabular}


522 Table 4. Data for manure solids applied, water:solids ratio, manure total $\mathrm{P}$ and $\mathrm{N}$ applied, and predicted $\mathrm{DRP}_{\text {and }} \mathrm{NH}_{4}-\mathrm{N}$ release for

523 both the liquid and semi-solid manures during the snowmelt leaching experiments.

\begin{tabular}{|c|c|c|c|c|c|c|}
\hline Rate & $\begin{array}{l}\text { Manure } \\
\text { Solids } \\
\text { Applied }^{1}\end{array}$ & $\begin{array}{l}\text { Water:Solids } \\
\text { Ratio }(\mathrm{W})^{2}\end{array}$ & $\begin{array}{l}\text { Manure Total } \\
\text { P Applied }\end{array}$ & $\begin{array}{l}\text { Manure Total } \\
\text { N Applied }\end{array}$ & $\begin{array}{l}\text { Predicted DRP } \\
\text { Release }^{3}\end{array}$ & $\begin{array}{c}\text { Predicted } \\
\mathrm{NH}_{4}-\mathrm{N} \\
\text { Release }\end{array}$ \\
\hline & $\mathrm{g}$ & $\mathrm{cm}^{3} \mathrm{~g}^{-1}$ & $\mathrm{mg}$ & $\mathrm{mg}$ & $\mathrm{mg}$ & $\mathrm{mg}$ \\
\hline & & & Liquid Manure & & & \\
\hline Low & 4.5 & 331.2 & 49.9 & 352.3 & 8.4 & 78.9 \\
\hline Medium & 9.1 & 174.0 & 99.9 & 704.7 & 10.3 & 146.6 \\
\hline \multirow[t]{2}{*}{ High } & 18.2 & 96.4 & 199.8 & 1409.4 & 7.7 & 282.2 \\
\hline & & & $\begin{array}{l}\text { Semi-solid } \\
\text { Manure }\end{array}$ & & & \\
\hline Low & 4.0 & 316.0 & 21.3 & 112.7 & 6.1 & 22.8 \\
\hline Medium & 8.6 & 144.0 & 45.3 & 239.5 & 10.6 & 44.7 \\
\hline High & 17.1 & 74.0 & 90.7 & 479.0 & 16.1 & 86.3 \\
\hline
\end{tabular}

${ }^{1}$ Dry weight equivalent

${ }^{2}$ Includes water in manure and $1250 \mathrm{~mL}$ snow water for semi-solid manure and $1400 \mathrm{~mL}$ for liquid manure

${ }^{3}$ Predictions use Eq. [1] for semi-solid manure and Eq. [2] for liquid manure

${ }^{4}$ Predictions use Eq. [3] 

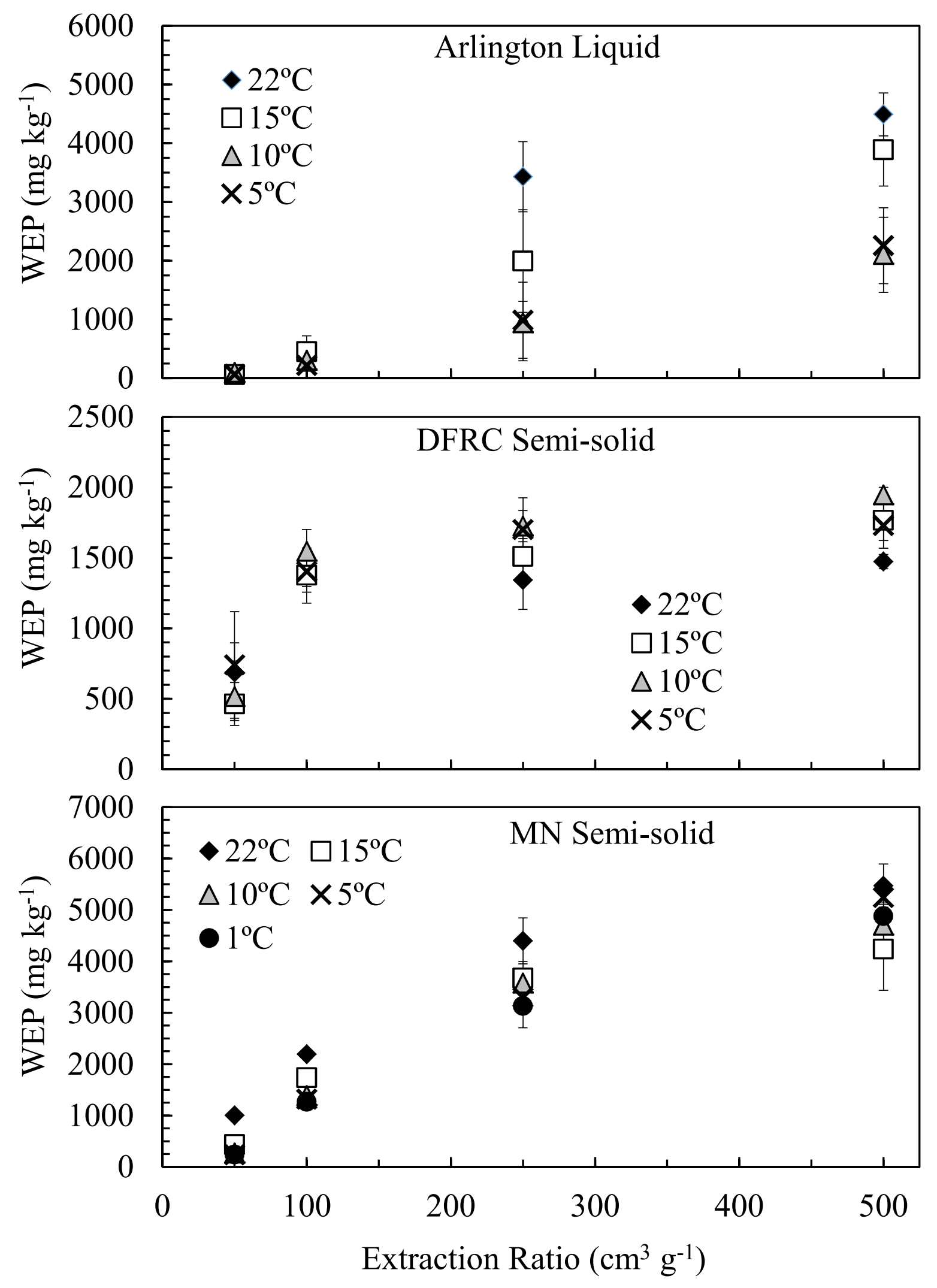
Figure 2.

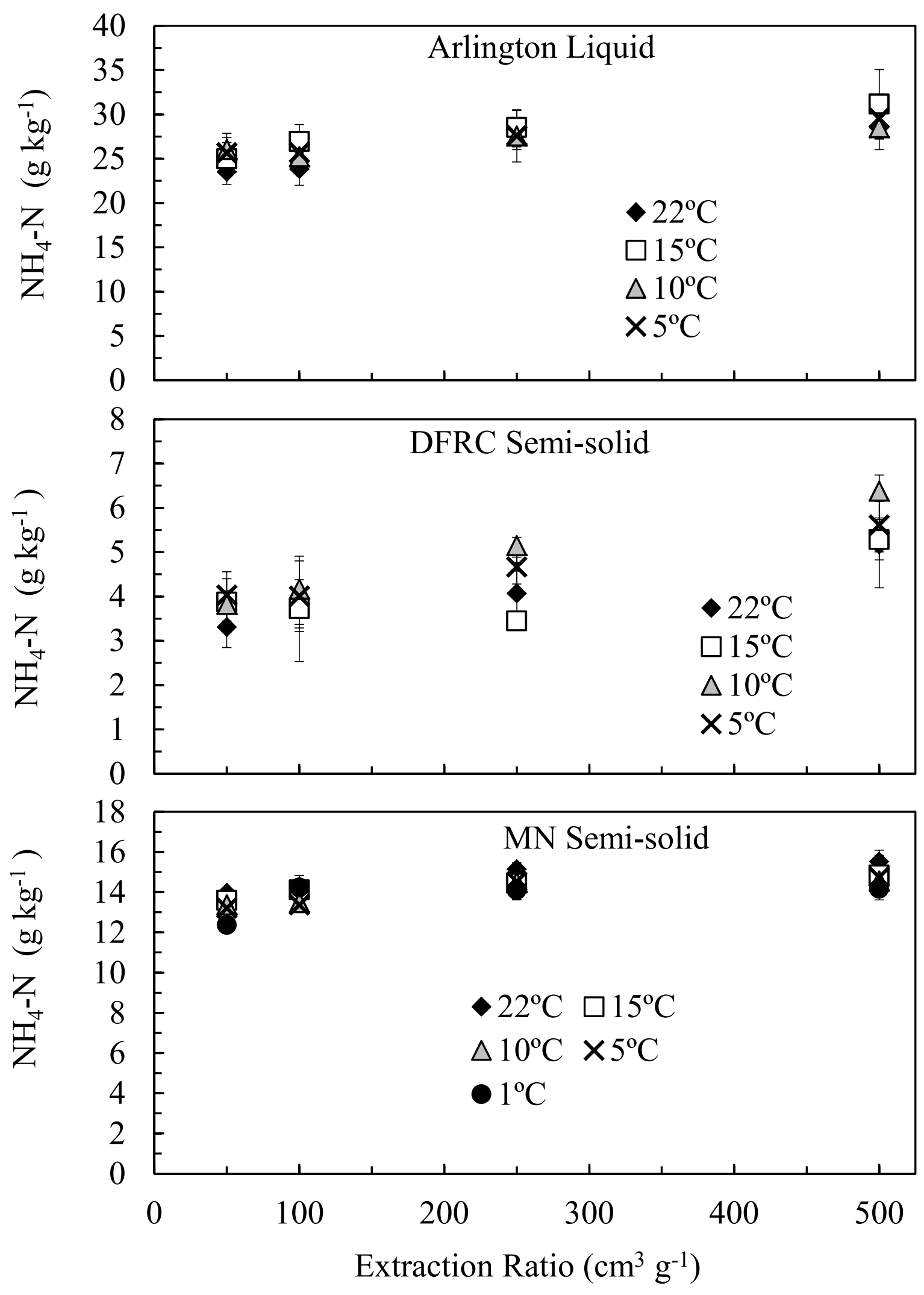


Figure 3
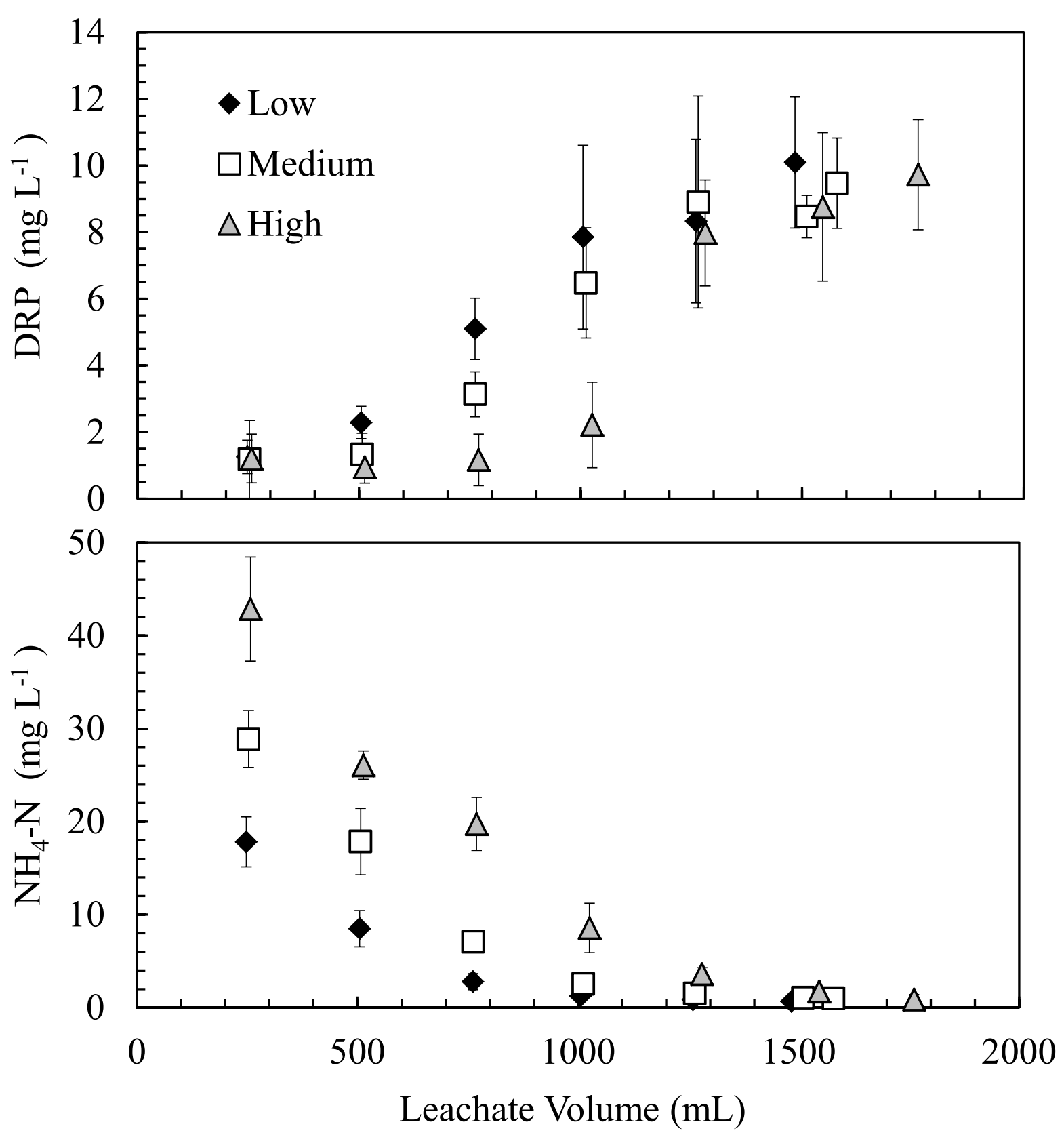
Figure 4
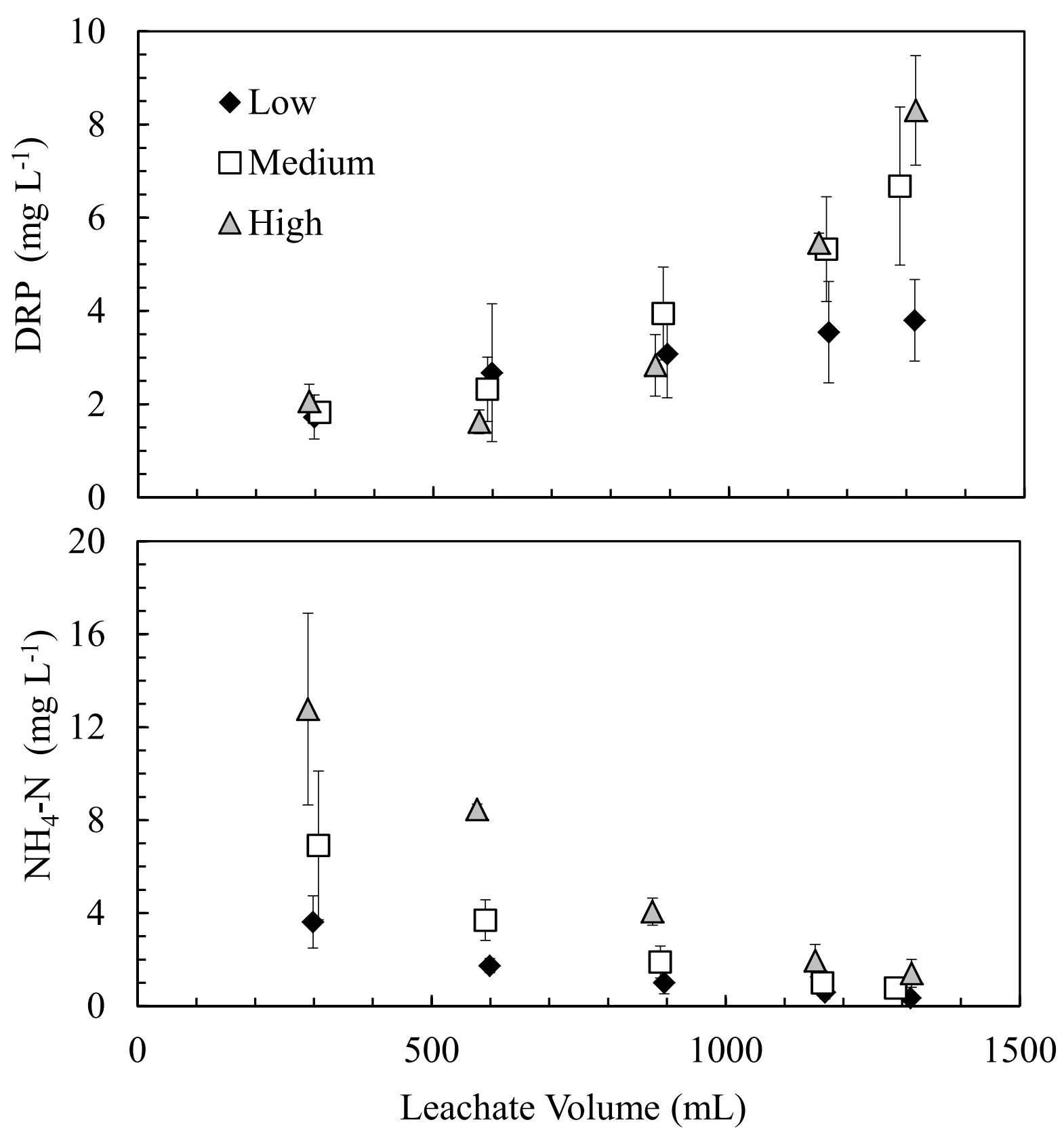
3

4 5 6

7

\section{Temperature and Manure Placement in a Snowpack Affect}

\section{Nutrient Release from Dairy Manure during Snowmelt}

Peter A. Vadas*, Melanie N. Stock, Gary W. Feyereisen, Francisco J. Arriaga, Laura W. Good, and K.G. Karthikeyan

P.A. Vadas, USDA-ARS, U.S. Dairy Forage Research Center, 1925 Linden Drive West,

Madison, WI 53706. M.N Stock, F.J. Arriaga, L.W. Good, and K.G. Karthikeyan, University of Wisconsin-Madison. G.W. Feyereisen, USDA-ARS, Soil and Water Management Research Unit, St Paul., MN. *Corresponding author: (peter.vadas@ars.usda.gov), 608-890-0069 (phone), 608890-0076 (fax).

13

14

15
$(7$ 
Abstract

Agricultural nutrient management is an issue due to nitrogen $(\mathrm{N})$ and phosphorus $(\mathrm{P})$ losses from fields and water quality degradation. Better information is needed on the risk of nutrient loss in runoff from dairy manure applied in winter. We investigated the effect of temperature on nutrient release from liquid and semi-solid manure to water, and of manure quantity and placement within a snowpack on nutrient release to melting snow. Temperature did not affect manure $\mathrm{P}$ and ammonium-N $\left(\mathrm{NH}_{4}\right)$ release during water extraction. Manure $\mathrm{P}$ release, but not $\mathrm{NH}_{4}-\mathrm{N}$ release, was significantly influenced by the water-to-manure solids extraction ratio. During snowmelt, manure $\mathrm{P}$ release was not significantly affected by manure placement in the snowpack, and the rate of $\mathrm{P}$ release decreased as application rate increased. Water extraction data can reliably estimate P release from manure during snowmelt; however, snowmelt water interaction with manure of greater solids content and subsequent $\mathrm{P}$ release appears incomplete compared to liquid manures. Manure $\mathrm{NH}_{4}-\mathrm{N}$ released during snowmelt was statistically the same regardless of application rate. For the semi-solid manure, $\mathrm{NH}_{4}-\mathrm{N}$ released during snowmelt increased with the depth of snow covering it, mostly likely due to reduced $\mathrm{NH}_{3}$ volatilization. For the liquid manure, there was no effect of manure placement within the snowpack on $\mathrm{NH}_{4}-\mathrm{N}$ released during snowmelt. Water extraction data can also reliably estimate manure $\mathrm{NH}_{4}-\mathrm{N}$ release during snowmelt as long as $\mathrm{NH}_{3}$ volatilization is accounted for with liquid manures for all placements in a snowpack and semi-solid manures applied on top of snow. 
Agricultural nutrient management continues to be an important area of scientific research and policy development due to concerns over $\mathrm{N}$ and $\mathrm{P}$ losses in surface runoff from farm fields and subsequent water quality degradation (Carpenter et al., 1998; Parris, 2011). Research has consistently shown that surface manure application to fields without incorporation can be a significant source of N and P loss (Daniel et al., 1998; Kleinman and Sharpley, 2003; Vadas et al., 2007). In many northern U.S. states, as well as Canadian provinces and northern European countries, winter application of dairy manure is common because it reduces the need for expensive manure storage, allows time for manure spreading when there are fewer on-field activities, and potentially reduces soil compaction from heavy equipment if soil is frozen (Srinivasan et al., 2006). Because soils are frozen, winter-applied dairy manure is typically surface applied and left unincorporated. This fact, combined with regular and significant runoff from snowmelt and rain-on-snow events, has prompted many states to restrict winter spreading of dairy manure (Srinivasan et al., 2006), including relatively new rules in Iowa (http://www.iowadnr.gov/About-DNR/DNR-News-Releases/ArticleID/1096). However, there has been relatively little research on nutrient loss from winter applied manure as support for restrictions, especially compared to research on manure nutrient loss during non-winter periods (see citations below).

The potential for manure nutrient runoff during winter is complex and can vary due to infiltration, runoff, erosion, and nutrient cycling processes, all of which are sensitive to air temperatures and frozen soil conditions. Nutrient loss may also vary with manure spreading practices, especially relative to manure placement beneath or on top of snow and the effect of manure on rates of snow melt (Kongoli and Bland, 2002). Detailed studies of soil and manure interactions and the hydrological processes that affect nutrient transport under winter conditions 
are limited. Most studies have been observational with mixed results regarding the degree to which winter manure application increases the risk of nutrient runoff relative to manure application in other seasons.- A majority of research was conducted before 1980 (Converse et al., 1976; Steenhuis et al., 1981; Young and Mutchler, 1976; Young and Holt, 1977; Klausner et al., 1976; Phillips et al., 1981). While there has been some more recent research (Hansen et al., 2000; Komiskey et al., 2011; Lewis and Makarewicz, 2009; Owens et al., 2011; Ulen, 2003), it was observational at the field-scale or larger, and did not provide data on liquid manures. The review paper of Srinivasan et al. (2006) details the results of most of these studies. Only the recent research of Williams et al. $(2011 ; 2012 b$, a) has investigated winter processes at the controlled lab scale. Overall, a process-level understanding of nutrient cycling and transport processes associated with winter manure application is lacking, especially for liquid manures.

\section{Our major research-goal is to investigate and-improve the understanding and modeling of} biochemical and physical processes controlling frozen-soil and snowmelt infiltration, runoff, and nutrient loss from soil and winter-applied dairy manure- We are addressing this goal through a series of lab and field-plot scale experiments. Lab experiments, such as the ones reported here, are designed to-investigate specific processes under controlled conditions at small scales rather than under variable weather at field scales, which combined can make it difficult to identify relative importance of multiple processes. The specific objectives in the current lab experiments were to 1) investigate if less $\mathrm{P}$ and $\mathrm{NH}_{4}$ are released from manure to water due to low temperatures that would occur during snowmelt (as compared to rain events in non-winter periods); 2) investigate the effect of dairy manure solids content, application amount, and placement within a snowpack on $\mathrm{P}$ and $\mathrm{NH}_{4}$ release to melting snow; and 3) determine if 
relationships from Objective 1 can reliably predict nutrient release from manure during snowmelt in Objective 2.

\section{Materials and Methods}

\section{Manure Extraction Experiments at Different Temperatures}

We collected three dairy manures from Holstein lactating cows: i) a liquid manure at the University of Wisconsin cattle research center in Arlington, WI (Arlington liquid); ii) a semisolid manure at the USDA Dairy Forage Research Center (DFRC semi-solid) farm in Prairie du Sac, WI; and iii) a semi-solid manure from a commercial farm in Minnesota (MN manure). The Arlington liquid manure was from a storage lagoon and had a solids content of $4.6 \%$ as determined gravimetrically after drying at $65^{\circ} \mathrm{C}$. Manure in the lagoon was from a barn flush system where bedding sand had been separated by gravity settling. On a dry-weight basis, total $\mathrm{N}$ content was $77.6 \mathrm{~g} \mathrm{~kg}^{-1}$, and total P content was $11.0 \mathrm{~g} \mathrm{~kg}^{-1}$. The DFRC (12.6\% solids) and MN (11.6\% solids) semi-solid manures were both collected from the floor of free-stall barns at the point of mechanical consolidation. For the DFRC manure, dry-weight-basis total $\mathrm{N}$ content was $28.0 \mathrm{~g} \mathrm{~kg}^{-1}$, and total $\mathrm{P}$ content was $5.3 \mathrm{~g} \mathrm{~kg}^{-1}$. For the MN manure, dry-weight-basis total $\mathrm{N}$ content was $43.8 \mathrm{~g} \mathrm{~kg}^{-1}$, and total $\mathrm{P}$ content was $9.0 \% \mathrm{~g} \mathrm{~kg}^{-1}$. Manures were stored at $4^{\circ} \mathrm{C}$ when not in use.

1 We conducted a series of manure extractions with water at different temperatures to investigate if cold temperatures that occur during snowmelt reduce nutrient release from manure compared to warmer temperatures during non-winter rain events. We conducted all extractions in triplicate. Our procedures followed those of Kleinman et al. (2002) and Vadas and 
115 Kleinman (2006) where fresh manure was shaken with deionized water for $1 \mathrm{~h}$ at different extraction ratios $\left(\mathrm{cm}^{3} \mathrm{~g}^{-1}\right.$, dry weight equivalent). Our extraction ratios included 50:1, 100:1, 250:1, and 500:1, and temperatures included $22,15,10$, and $5^{\circ} \mathrm{C}$. The $\mathrm{MN}$ manure was also extracted at $1^{\circ} \mathrm{C}$. For extractions, we weighed manure and water into separate flasks, placed them into a temperature-controlled shaker and let them equilibrate to the desired temperature for at least $24 \mathrm{~h}$ without shaking. We then combined the water and manure, shook the mixtures for $1 \mathrm{~h}$, and filtered them through $0.45 \mu \mathrm{m}$ filters. We analyzed the filtered samples for dissolved reactive P (DRP) colorimetrically (Murphy and Riley, 1962) on a spectrophotometer, and for $\mathrm{NH}_{4}-\mathrm{N}$ and $\mathrm{NO}_{3}-\mathrm{N}$ on a Lachat automated analyzer (Hach Company, Loveland, $\mathrm{CO}$ ) using QuickChem Methods 12-107-06-2-A (ammonium) and 12-107-04-1-B (nitrate). Throughout the experiments, $\mathrm{NO}_{3}-\mathrm{N}$ concentrations in manure extractions and snowmelt leachings (see below) were negligible, so we do not present data for this $\mathrm{N}$ form.

\section{Snowmelt Leaching Experiments}

We designed these experiments to investigate nutrients release from manure to melting snow water. This is the first step in understanding and modeling potential manure nutrient transport in runoff. We therefore conducted experiments with snow and manure only, in the absence of underlying soil. We used only the Arlington liquid manure and DFRC semi-solid manure for these leaching experiments. We conducted experiments in triplicate using $15-\mathrm{cm}$ diameter funnels that had flat bottoms and a series of small drainage holes. We collected natural snow and stored it frozen until use. We added snow and manure to funnels to achieve three rates of manure, and three manure placements in a snowpack, which were below snow, between two equivalent snow layers, and on top of snow. For the liquid manure, we added a snow equivalent 
of $1400 \mathrm{~mL}$ of water and manure at three wet-weight amounts of 98, 197 and $394 \mathrm{~g}$. This achieved a relatively wide range of liquid (including snow and manure liquid) to manure dry matter ratios of 96,174 , and $331 \mathrm{~cm}^{3} \mathrm{~g}^{-1}$ (Table 4). For the semi-solid manure, we added a snow equivalent of $1250 \mathrm{~mL}$ of water and manure at wet-weight rates of 32, 68 and $136 \mathrm{~g}$. This achieved liquid to manure dry matter ratios of 74,144 , and $315 \mathrm{~cm}^{3} \mathrm{~g}^{-1}$ (Table 4). For each funnel, we froze a piece of acid-washed, nylon screen in $30 \mathrm{~mL}$ of deionized water and placed the screen in the funnel before adding any manure or snow. This prevented any immediate loss of manure through funnels before snowmelt began. When assembled, we placed all funnels in a cold room ef aboutat approximately $4^{\circ} \mathrm{C}$ and allowed snow to melt, which took between 44 to 58 h. During melt, we collected all leachate in increments of every $250-300 \mathrm{~mL}$. We filtered and analyzed all samples for $\mathrm{NH}_{4}$ and $\mathrm{P}$ as described above.

\section{Statistical Analysis}

We used the general linear model of SAS (SAS Version 9.4) along with Tukey's mean separation to conducted a statistical analysis of results. For the water extraction experiment, variables of DRP and $\mathrm{NH}_{4}-\mathrm{N}$, total treatment sums of squares (SS) for the fixed effects in the ANOVA were partitioned into partial SS associated with the three manure types, four extraction ratios, five temperatures, and all their two-way and three-way treatment interactions. We used partial SS to determine the percentage of total DRP and $\mathrm{NH}_{4}-\mathrm{N}$ associated with each treatment effect or treatment interaction. Treatment differences discussed in the text were significant at the 0.05 probability level. We conducted a similar statistical analysis for the funnel leaching experiments, where fixed effects were the two manure types, three application rates, three placements in the snowpack, and all their two-way and three-way treatment interactions. 


\section{Results and Discussion}

\section{Manure Extraction Experiments}

Throughout the discussion, we refer to DRP analyzed in manure extractions as water extractable $\mathrm{P}$ (WEP) to be consistent with terminology in previous studies on manure $\mathrm{P}$ extractability (Kleinman et al., 2002; Vadas and Kleinman, 2006; Kleinman et al., 2005). Figure 1 shows results for manure WEP ( $\mathrm{mg} \mathrm{kg}^{-1}$ dry weight equivalent) for the three dairy manures as a function of extraction ratio and temperature. Statistical analysis indicated that only extraction ratio had a significant effect on WEP, and explained $60 \%$ of its variability (Table 1 ). This was true for WEP expressed on a mass basis ( $\mathrm{mg} \mathrm{kg}^{-1}$ dry weight equivalent) or as a percent of total $\mathrm{P}$ in the manure. Manure type and the manure by extraction ratio interaction each explained $16 \%$ of WEP variability, but were not statistically significant. Across all three manures, temperature did not significantly affect WEP, even though there was less WEP from the Arlington liquid manure as temperature decreased from $22^{\circ} \mathrm{C}$ to $10^{\circ} \mathrm{C}$, with no further decrease less than $10^{\circ} \mathrm{C}$. This suggests cold temperatures do not affect P release from manure substantially enough that models need to account for the variable (Bechmann et al., 2005).

Figure 2 shows results for water extractable manure $\mathrm{NH}_{4}-\mathrm{N}$ as a function of extraction ratio and temperature. Statistical analysis showed that only manure type had a significant effect on extractable $\mathrm{NH}_{4}-\mathrm{N}$, and explained $98 \%$ of the data variability (Table 1). There was greater extractable $\mathrm{NH}_{4}-\mathrm{N}$ for the liquid manure than the semi-solid manures, which did not differ from each other. While this statistical effect of manure type was true on a mass basis $\left(\mathrm{mg} \mathrm{kg}^{-1} \mathrm{dry}\right.$ weight equivalent), it was not true for $\mathrm{NH}_{4}-\mathrm{N}$ expressed as a percent of total $\mathrm{N}$ in manure. Since total $\mathrm{N}$ content varied from 28.0 to $77.6 \mathrm{~g} \mathrm{~kg}^{-1}$ across manures, comparing data as a percent of 
total $\mathrm{N}$ may be more equitable. Given that, Figure 2 shows that manure $\mathrm{NH}_{4}-\mathrm{N}$ release to water was fairly rapid and complete regardless of temperature, extraction ratio, or manure type. Good (2002) also observed no effect of extraction ratio on manure $\mathrm{NH}_{4}-\mathrm{N}$ release. This suggests that models do not need to account for these variables when estimating $\mathrm{NH}_{4}-\mathrm{N}$ release from manure during snowmelt.

\section{Phosphorus Dynamics during Snowmelt Leaching}

leachate for both the liquid manure and the DFRC semi-solid manure increased as snowmelt progressed. These data are consistent with our lab extraction data that DRP release is a function of how much water interacts with manure. Thus during snowmelt when liquid water interaction with manure is gradual, DRP release is more likely to increase as snowmelt proceeds and leads to interaction with more water (Kleinman et al., 2002).

Table 3 presents cumulative manure DRP released $(\mathrm{mg})$ for both the liquid and semisolid manures over the entire snowmelt period. Statistical analysis in Table 2 shows that on a mass basis (mg) there was no effect of manure type, placement in the snowpack, or application rate on cumulative DRP released. However, when expressed as a percent of total manure P applied, there was an effect of application rate on cumulative DRP released (Table 2). This means that Thus, the proportion of applied manure total $\mathrm{P}$ that leached decreased as application rate increased. The three manure application rates during snowmelt represented about 50, 100, and $200 \mathrm{mg}$ applied total $\mathrm{P}$ for the liquid manure and 21, 45, and $91 \mathrm{mg}$ for the DFRC semi-solid manure for the high, medium, and low application rates, respectively (Table 4). Therefore, the 
amount of manure DRP leached during snowmelt was about 5, 9, and 17\% of total P applied for the high, medium, and low application rates for both manures. These results are consistent with our lab extraction data showing that $\mathrm{P}$ leaching is a function of the water:solids extraction ratio and that a greater percentage of manure $\mathrm{P}$ is released at greater ratios (Vadas et al., 2004; Vadas et al., 2005). In the snowmelt leaching experiments, as the amount of applied manure increased, the ratio of snow water to manure solids (equivalent to extraction ratio during the water extraction experiments) decreased, and thus the percentage of applied $\mathrm{P}$ that was released also decreased.

There was no significant effect of manure placement within the snowpack on cumulative DRP released (Tables 2 and 3). Young and Mutchler (1976) suggested that manure applied below snow may have greater potential to interact with liquid snowmelt water and lose more nutrients in runoff. However, in controlled laboratory experiments using soil boxes, Williams et al. (2011) found less P loss in runoff from manure applied below snow compared to on top of or within snow and suggested this was because manure remained frozen below snow (due to influence of frozen soil) and was less susceptible to P loss. Phosphorus loss in runoff was the same for manure applied on top of or within snow. Our experiments did not have underlying soil and are not strictly comparable to these runoff studies. However, our data are consistent with those of Williams et al. (2011) for manure applied on top of or within snow, and suggest that snowmelt water interaction with manure and release of $\mathrm{P}$, and thus potential $\mathrm{P}$ loss in snowmelt runoff, is functionally similar regardless of where manure is in the snowpack. Instead, site snowmelt dynamics, degree of snowmelt water interaction with manure, and runoff hydrology are likely more dominant mechanisms controlling manure $\mathrm{P}$ release during snowmelt and potential loss in runoff than manure placement in the snowpack (Kongoli and Bland, 2002). This 
suggests nutrient runoff models do not need to account for manure placement in a snowpack for P.

Vadas et al. $(2004 ; 2005)$ showed that manure water extraction data such as those in

Figure 1 can be used to reliably estimate how much DRP is leached from manure during a rain event. The equation used in that research to estimate DRP leached from manure by rain was:

where $\mathrm{W}$ is the water to manure extraction ratio $\left(\mathrm{cm}^{3} \mathrm{~g}^{-1}\right)$, WEP is the manure DRP that is extracted (in mass units such as $\mathrm{mg}$ or $\mathrm{mg} \mathrm{kg}^{-1}$ ) at a W of 250:1 over $1 \mathrm{~h}$, and DRP release is in the same units as WEP. Equation [1] fit well to the lab extraction data for the DFRC semi-solid manure in Figure $1\left(\mathrm{r}^{2}=0.70\right)$, so we applied Eq. [1] to see if it could reliably estimate DRP release from manure during our snowmelt leaching experiments. For the semi-solid manure, manure solids application rates and $\mathrm{W}$ values during snowmelt leaching are in Table 4 . We estimated a manure WEP of $1560 \mathrm{mg} \mathrm{kg}^{-1}$ based on data at the 250:1 extraction ratio in Figure 1. Applying Eq. [1] resulted in estimated DRP release amounts of 16.1, 10.6, and $6.1 \mathrm{mg}$ for the high, medium, and low application rates, respectively (Table 4). Corresponding measured rates as averaged across manure placements in snow were 4.7, 4.5, and $3.7 \mathrm{mg}$ for high, medium, and low application rates (Table 3).

Clearly, less DRP was leached from the semi-solid manure during snowmelt than Eq. [1] would estimate. If we assume that the basic leaching processes represented by Eq. [1] still applied, underestimated DRP leaching suggests that not all the snowmelt water interacted with manure and that $\mathrm{W}$ as applied in Eq. [1] should have been less. In fact, the degree to which 
measured DRP release was less than that estimated by Eq. [1] was consistent. We calculated that if only $20 \%$ of snowmelt water actually interacted with manure, then Eq. [1] W values would be 15,29 , and $63 \mathrm{~cm}^{3} \mathrm{~g}^{-1}$; and corresponding estimated DRP release would be $4.7,4.5$, and $3.5 \mathrm{mg}$, for the high, medium, and low application rates, respectively. These estimated DRP release values are similar to measured values (Table 3).

Overall, our snowmelt leaching and water extraction data results suggest that for semisolid manures Eq. [1] can be used in models to estimate DRP release from manure during snowmelt, and that DRP release is not a function of temperature or manure placement in a snowpack during snowmelt. However, the amount of snowmelt water that actually interacts with the manure and subsequent DRP release is significantly less compared to water interaction with manure during a rain event. During modeling research using Eq. [1] to simulate P loss in runoff from winter applied manure, Vadas et al. (2017) found that field scale runoff data also indicated incomplete interaction of snowmelt water with solid beef manure. Clearly, this possibility of incomplete snowmelt water interaction with solid manure and reduced DRP release deserves further investigation, especially as we could find no infermation in the-literature on thise topic. For the Arlington liquid manure, Eq. [1] did not effectively describe the lab WEP extraction data in Figure $1\left(r^{2}=0.05\right)$. The reason for this is unknown, but could be related to manure P mineralogy, which can be a function of animal diet or bedding material (Pagliari, 2011). The liquid manure WEP extraction data instead exhibited a linear increase in manure WEP with W, while Eq. [1] is nonlinear. Therefore, we used data from Figure 1 (as averaged across all temperatures) to represent DRP release from the liquid manure as:

DRP release $=(0.005 \mathrm{~W}-0.253)($ manure WEP $) \quad \mathrm{r}^{2}=0.96$ 
277 For the liquid manure, manure solids application amounts and W values are in Table 4. We

278 estimated a manure WEP of $1840 \mathrm{mg} \mathrm{kg}^{-1}$ based on data at the 250:1 extraction ratio in Figure 1. Applying Eq. [2] resulted in manure DRP release amounts of 8.4, 10.3 and $7.7 \mathrm{mg}$ for the high, medium, and low application rates, respectively (Table 4). Corresponding measured rates were 7.8, 8.0, and $8.6 \mathrm{mg}$ for the high, medium, and low application rates (Table 3). Similar to the DFRC semi-solid manure, these liquid manure results suggest that lab water extraction data can be used to estimate DRP release from manure during snowmelt, without considering temperature or manure placement in a snowpack during snowmelt. Data also demonstrate that when estimating DRP release from a liquid manure during snowmelt, incomplete snowmelt water interaction with manure does not need to be considered. This may be because liquid manure is more evenly distributed and absorbed into the snowpack than a semi-solid manure, and thus has a potential for greater snowmelt interaction. As before, this possibility of more complete snowmelt interaction with liquid manure but incomplete snowmelt water interaction with more solid manure deserves further investigation.

\section{Nitrogen Dynamics during Snowmelt Leaching}

In all leaching experiments, $\mathrm{NH}_{4}-\mathrm{N}$ concentrations in snow water without manure were

less than $0.30 \mathrm{mg} \mathrm{L}^{-1}$. Results in Figures 3 and 4 show that $\mathrm{NH}_{4}-\mathrm{N}$ concentrations in incremental leachate water from both the liquid and semi-solid manures decreased as snowmelt progressed.

These data are consistent with our lab extractions that showed $\mathrm{NH}_{4}-\mathrm{N}$ release is not a function of 
Statistical analysis in Table 2 shows that only manure type had a significant effect on mass (mg) of cumulative $\mathrm{NH}_{4}-\mathrm{N}$ leached during snowmelt (Table 3). However, when $\mathrm{NH}_{4}-\mathrm{N}$ release was expressed as a function of total $\mathrm{N}$ applied in manure, no treatment variables had a significant effect on $\mathrm{NH}_{4}-\mathrm{N}$ leached (Table 2). This means that Thus, a similar percentage of applied total $\mathrm{N}$ leached from manure regardless of application rate and thus snow water:manure solids ratio. For both manures, an average of $19.2 \%$ (s.d. of $2.3 \%$ ) of applied manure total $\mathrm{N}$ was leached.

For the semi-solid manure, although placement in the snowpack was not a significant factor (Table 2), the amount of $\mathrm{NH}_{4}-\mathrm{N}$ leached during snowmelt consistently increased with the depth of snow covering it (Table 3). This is most likely because manure applied on top of snow, and even between snow layers, had longer direct exposure to the air above it, had greater $\mathrm{NH}_{3}$ volatilization, and thus had less $\mathrm{NH}_{4}-\mathrm{N}$ available for leaching loss (Williams et al., 2011; Lauer et al., 1976). Steenhuis et al. (1979) observed about $35 \%$ greater $\mathrm{NH}_{3}$ volatilization from a dairy manure (16\% solids) placed on top of a snow pack compared to below a $10 \mathrm{~cm}$ snowpack over four days. Similarly, we observed about $30 \%$ more $\mathrm{NH}_{4}-\mathrm{N}$ in leachate from our semi-solid manure when manure was below the snowpack compared to on top. An average of $20.6 \%$ (s.d. of $1.7 \%$ ), $18.6 \%$ (s.d. of $1.5 \%$ ), and $13.5 \%$ (s.d. of $0.7 \%$ ) of applied manure total $\mathrm{N}$ was leached as $\mathrm{NH}_{4}-\mathrm{N}$ for the manure below, in between, and on top of snow, respectively. For the liquid manure at a given manure application rate, there was no trend of manure placement within the snowpack on $\mathrm{NH}_{4}-\mathrm{N}$ leached during snowmelt (Table 3). An average of $20.9 \%$ (s.d. of $2.3 \%$ ) of manure total $\mathrm{N}$ was leached as $\mathrm{NH}_{4}-\mathrm{N}$. Therefore, our data suggest that $\mathrm{NH}_{3}$ volatilization may not vary as a function of placement in a snowpack for liquid manure. 

release from manure during snowmelt. Combining the data from all three manures in Figure 2, we developed the equation below (similar to Eqs. [1] and [2]):

Solids application rates and $\mathrm{W}$ values during snowmelt leaching are in Table 4 . We estimated manure $\mathrm{NH}_{4}-\mathrm{N}$ from maximum amounts extracted during water extractions (Figure 2). Applying for the high, medium, and low application rates, respectively (Table 4). Corresponding average measured $\mathrm{NH}_{4}-\mathrm{N}$ release rates when manure was applied below or between snow layers were 88.6, 45.7, and $24.0 \mathrm{mg}$ (Table 3). Therefore, Eq. [3] reliably estimated manure $\mathrm{NH}_{4}-\mathrm{N}$ release for these two manure placements. However, corresponding measured $\mathrm{NH}_{4}-\mathrm{N}$ release rates when manure was applied on top of snow was 64.3, 30.7, and $15.9 \mathrm{mg}$ (Table 3). Therefore, Eq. [3] over-estimated manure $\mathrm{NH}_{4}-\mathrm{N}$ release for this manure placement. It is reasonable to assume that overprediction is due to unaccounted for $\mathrm{NH}_{3}$ volatilization from manure applied on top of snow. In fact, if we assume a $\mathrm{NH}_{3}$ volatilization rate of $35 \%$ for manure applied on top of snow, as reported by Steenhuis et al. (1979) (i.e., 35\% less manure $\mathrm{NH}_{4}-\mathrm{N}$ available to leach), predicted $\mathrm{NH}_{4}-\mathrm{N}$ release in snowmelt would be $56.1,29.0$, and $14.8 \mathrm{mg}$, which is close to measured values. Converse to $\mathrm{P}$, these data also demonstrate that when estimating manure $\mathrm{NH}_{4}-\mathrm{N}$ release from a semi-solid manure during snowmelt, incomplete snowmelt water interaction with manure does not need to be considered. This may be because $\mathrm{NH}_{4}-\mathrm{N}$ release is much less sensitive to the amount of water that interacts with manure (Fig. 2). 
For the liquid manure, manure solids application rates and $\mathrm{W}$ values are in Table 4.

Applying Eq. [3] resulted in predicted $\mathrm{NH}_{4}-\mathrm{N}$ release amounts of 479.0, 239.5, and $112.7 \mathrm{mg}$ for the high, medium, and low application rates, respectively (Table 4). Corresponding measured $\mathrm{NH}_{4}-\mathrm{N}$ release rates were clearly much less at $266.7,150.1$, and $79.5 \mathrm{mg}$ (Table 3 ). If we attribute overprediction to $\mathrm{NH}_{3}$ volatilization from applied manure, a volatilization rate of $35 \%$ of applied manure $\mathrm{NH}_{4}-\mathrm{N}$ would result in predicted $\mathrm{NH}_{4}-\mathrm{N}$ release during snowmelt of 282.2 , 146.6, and $78.9 \mathrm{mg}$, which agreed well with measured rates. Overall, our data suggest that water extraction data can be used to reliably estimate manure $\mathrm{NH}_{4}-\mathrm{N}$ release during snowmelt without having to consider temperature or $\mathrm{NH}_{3}$ volatilization if a semi-solid to solid manure is covered by snow. However, $\mathrm{NH}_{3}$ volatilization needs to be accounted for with liquid manures at all placements in a snowpack and a semi-solid manure applied on top of snow.

\section{Conclusions}

Our lab-scale experiments suggest that temperature may not significantly influence manure WEP and $\mathrm{NH}_{4}-\mathrm{N}$ release to water. Also, manure WEP release, but not $\mathrm{NH}_{4}-\mathrm{N}$ release, to water will be influenced by the water-to-manure solids ratio. Manure placement within a snowpack may not significantly influence snowmelt interaction with manure and leaching of DRP. For semi-solid manures, the amount of $\mathrm{NH}_{4}-\mathrm{N}$ leached during snowmelt can increase with the depth of snow covering it. This is mostly likely because manure applied on top of snow, and even between snow layers, has greater $\mathrm{NH}_{3}$ volatilization and thus less $\mathrm{NH}_{4}-\mathrm{N}$ available for leaching loss. For liquid manures, $\mathrm{NH}_{3}$ volatilization may not vary as a function of placement in a snowpack, but liquid manures applied to snow will have greater $\mathrm{NH}_{3}$ volatilization than more solid manures unless the solid manures are applied on top of snow and have significant $\mathrm{NH}_{3}$ 
volatilization. Finally, lab water extractions can be used to reliably estimate manure $\mathrm{NH}_{4}-\mathrm{N}$

release during snowmelt, but variations in $\mathrm{NH}_{3}$ volatilization need to be accounted for with liquid manures at all placements in a snowpack and a semi-solid manure applied on top of snow.

Lab water extractions can also be used to estimate DRP release from manure during snowmelt; but for semi-solid to solid manures, the amount of snowmelt water that actually interacts with the manure and subsequent WEP release is significantly less compared to water interaction with manure during a rain event. The same is not true for liquid manures applied to snow. This may be because liquid manure is more evenly distributed and absorbed into a snowpack than a semisolid manure, and thus has a greater potential for complete snowmelt interaction. This possibility of more complete snowmelt interaction with liquid manures but incomplete snowmelt water interaction with more solid manure during DRP release deserves further investigation, especially as a function of a range of manure solids content. Overall, our data will help improve simulation models that can be applied to explore the management and environmental implications of winter $\underline{\text { manure spreading and variable winter runoff conditions. }}$

\section{References}

Bechmann, M.E., P.J.A. Kleinman, A.N. Sharpley, and L.S. Saporito. 2005. Freeze-thaw effects on phosphorus loss in runoff froin manured and catch-cropped soils. J. Environ. Qual. 34:2301-2309.

Carpenter, S.R., N.F. Caraco, D.L. Correll, R.W. Howarth, A.N. Sharpley, and V.H. Smith. 1998. Nonpoint pollution of surface waters with phosphorus and nitrogen. Ecol. Appl. 8:559-568.

Converse, J.C., G.D. Bubenzer, and W.H. Paulson. 1976. Nutrient Losses in Surface Runoff from Winter Spread Manure. Trans. ASAE 19:517-519.

Daniel, T.C., A.N. Sharpley, and J.L. Lemunyon. 1998. Agricultural phosphorus and eutrophication: A symposium overview. J. Environ. Qual. 27:251-257.

Good, L.W. 2002. Mechanisms controlling phosphorus loss to water from animal manures and manure-amended soils. Ph.D. diss., Univ. Wisconsin, Madison.

Hansen, N.C., S.C. Gupta, and J.F. Moncrief. 2000. Snowmelt runoff, sediment, and phosphorus losses under three different tillage systems. Soil Till Res 57:93-100. 
Klausner, S.D., P.J. Zwerman, and D.F. Ellis. 1976. Nitrogen and Phosphorus Losses from Winter Disposal of Dairy Manure. J. Environ. Qual. 5:47-49.

Kleinman, P.J.A., and A.N. Sharpley. 2003. Effect of broadcast manure on runoff phosphorus concentrations over successive rainfall events. J. Environ. Qual. 32:1072-1081.

Kleinman, P.J.A., A.N. Sharpley, A.M. Wolf, D.B. Beegle, and P.A. Moore. 2002. Measuring water-extractable phosphorus in manure as an indicator of phosphorus in runoff. Soil Sci. Soc. Am. J. 66:2009-2015.

Kleinman, P.J.A., A.M. Wolf, A.N. Sharpley, D.B. Beegle, and L.S. Saporito. 2005. Survey of water-extractable phosphorus in livestock manures. Soil Sci. Soc. Am. J. 69:701-708.

Komiskey, M.J., T.D. Stuntebeck, D.R. Frame, and F.W. Madison. 2011. Nutrients and sediment in frozen-ground runoff from no-till fields receiving liquid-dairy and solid-beef manures. J. Soil Water Conserv. 66:303-312.

Kongoli, C.E., and W.L. Bland. 2002. Influence of manure application on surface energy and snow cover: Field experiments. J. Environ. Qual. 31:1166-1173.

Lauer, D.A., D.R. Bouldin, and S.D. Klausner. 1976. Ammonia Volatilization from Dairy Manure Spread on Soil Surface. J. Environ. Qual. 5:134-141.

Lewis, T.W., and J.C. Makarewicz. 2009. Winter application of manure on an agricultural watershed and its impact on downstream nutrient fluxes. J Great Lakes Res 35:43-49.

Murphy, J., and J.P. Riley. 1962. A Modified Single Solution Method for Determination of Phosphate in Natural Waters. Anal. Chim. Acta 27:31-36.

Owens, L.B., J.V. Bonta, M.J. Shipitalo, and S. Rogers. 2011. Effects of Winter Manure Application in Ohio on the Quality of Surface Runoff. J. Environ. Qual. 40:153-165.

Pagliari, P.H. 2011. Investigation of inorganic and organic phosphorus in animal manure and their effects on soil test phosphorus. Ph.D. diss., Univ. Wisconsin, Madison.

Parris, K. 2011. Impact of Agriculture on Water Pollution in OECD Countries: Recent Trends and Future Prospects. Int J Water Resour D 27:33-52.

Phillips, P.A., J.L.B. Culley, F.R. Hore, and N.K. Patni. 1981. Pollution Potential and Corn Yields from Selected Rates and Timing of Liquid Manure Applications. Trans. ASAE 24:139-144.

Srinivasan, M.S., R.B. Bryant, M.P. Callahan, and J.L. Weld. 2006. Manure management and nutrient loss under winter conditions: A literature review. J. Soil Water Conserv. 61:200209.

Steenhuis, T.S., G.D. Bubenzer, and J.C. Converse. 1979. Ammonia Volatilization of Winter Spread Manure. Trans. ASAE 22:152-\&.

Steenhuis, T.S., G.D. Bubenzer, J.C. Converse, and M.F. Walter. 1981. Winter-Spread Manure Nitrogen Loss. Trans. ASAE 24:436-442.

Ulen, B. 2003. Concentrations and transport of different forms of phosphorus during snowmelt runoff from an illite clay soil. Hydrological Processes 17:747-758.

Vadas, P.A., L.W. Good, W.E. Jokela, K.G. Karthikeyan, F.J. Arriaga, and M. Stock. 2017. Quantifying the impact of seasonal and short-term manure application decisions on phosphorus loss in surface runoff. J. Envrion. Qual. 46:doi:10.2134/jeq2016.2106.0220.

Vadas, P.A., B.E. Haggard, and W.J. Gburek. 2005. Predicting dissolved phosphorus in runoff from manured field plots. J. Environ. Qual. 34:1347-1353.

Vadas, P.A., R.D. Harmel, and P.J.A. Kleinman. 2007. Transformations of soil and manure phosphorus after surface application of manure to field plots. Nutr. Cycl. Agroeco. 77:8399. 
Vadas, P.A., and P.J.A. Kleinman. 2006. Effect of methodology in estimating and interpreting water-extractable phosohorus in animal manures. J. Environ. Qual. 35:1151-1159.

Vadas, P.A., P.J.A. Kleinman, and A.N. Sharpley. 2004. A simple method to predict dissolved phosphorus in runoff from surface-applied manures. J. Environ. Qual. 33:749-756.

Williams, M.R., G.W. Feyereisen, D.B. Beegle, and R.D. Shannon. 2012a. Soil Temperature Regulates Nitrogen Loss from Lysimeters Following Fall and Winter Manure Application. Trans. ASABE 55:861-870.

Williams, M.R., G.W. Feyereisen, D.B. Beegle, and R.D. Shannon. 2012b. Soil Temperature Regulates Phosphorus Loss from Lysimeters Following Fall and Winter Manure Application. Trans. ASABE 55:871-880.

Williams, M.R., G.W. Feyereisen, D.B. Beegle, R.D. Shannon, G.J. Folmar, and R.B. Bryant. 2011. Manure Application under Winter Conditions: Nutrient Runoff and Leaching Losses. Trans. ASABE 54:891-899.

Young, R.A., and R.F. Holt. 1977. Winter-Applied Manure - Effects on Annual Runoff, Erosion, and Nutrient Movement. J. Soil Water Conserv. 32:219-222.

Young, R.A., and C.K. Mutchler. 1976. Pollution Potential of Manure Spread on Frozen Ground. J. Environ. Qual. 5:174-179.

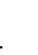

.

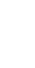

.

.

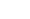


Figure Captions

Figure 1. Manure WEP release for the Arlington liquid dairy manure and the DFRC and MN semi-solid dairy manures during water extraction experiments as a function of extraction temperature and extraction ratio (water to manure solids, $\mathrm{cm}^{3} \mathrm{~g}^{-1}$ ). Letters-Bars indicate a significant effect of temperature $(\mathrm{p}=0.05)$ at that specific extraction ratio onlythe standard deviation of the means.

Figure 2. Manure $\mathrm{NH}_{4}-\mathrm{N}$ release for the Arlington liquid dairy manure and the DFRC and MN semi-solid dairy manures during water extraction experiments as a function of extraction deviation of the means. 
497 Figure 3. Change in dissolved $\mathrm{P}$ and $\mathrm{NH}_{4}-\mathrm{N}$ concentrations in snowmelt water with increasing 498 leachate volume during snowmelt leaching experiments with the Arlington liquid dairy manure 499 applied at three different rates. Data for a given rate are averaged across manure placements in 500 the snowpack. Bars indicate the standard deviation of the means.

Figure 4. Change in dissolved $\mathrm{P}$ and $\mathrm{NH}_{4}-\mathrm{N}$ concentrations in snowmelt water with increasing

504 leachate volume during snowmelt leaching experiments with the DFRC semi-solid dairy manure applied at three different rates. Data for a given rate are averaged across manure placements in the snowpack. Bars indicate the standard deviation of the means. 
509 Table 1. ANOVA for effects of manure, extraction ratio, and temperature on manure $\mathrm{WEP}$ and $\mathrm{NH}_{4}-\mathrm{N}$ extracted during water

510 extraction experiments. Data are presented for concentrations $\left(\mathrm{mg} \mathrm{kg}^{-1}\right)$ as well percent of total $\mathrm{P}$ or total $\mathrm{N}$ in manure.

\begin{tabular}{lcccccccccc}
\hline Source of Treatment Variation & \multicolumn{4}{c}{ WEP } & \multicolumn{2}{c}{ Percent of Total P } & \multicolumn{2}{c}{$\mathrm{NH}_{4}-\mathrm{N}$} & & \multicolumn{2}{c}{ Percent of Total N } \\
\hline & Df & P-Value & \% Trt & P-Value & $\%$ Trt & P-Value & $\%$ Trt & P-Value & $\%$ Trt \\
& 2 & 0.1471 & 16.4 & 0.1917 & 17.3 & 0.0017 & 97.7 & 0.1376 & 90.9 \\
Manure & 3 & 0.0044 & 58.2 & 0.0077 & 62.8 & 0.9792 & 1.2 & 0.9645 & 5.9 \\
Ratio & 4 & 0.9553 & 2.8 & 0.9821 & 2.0 & 1.0000 & 0.1 & 1.0000 & 0.2 \\
Temperature & 6 & 0.6822 & 16.0 & 0.8775 & 11.5 & 1.0000 & 0.4 & 1.0000 & 0.8 \\
Manure * Ratio & 6 & 0.9952 & 2.7 & 0.9964 & 2.9 & 1.0000 & 0.3 & 1.0000 & 1.2 \\
Manure * Temperature & 12 & 1.0000 & 0.9 & 1.0000 & 0.7 & 1.0000 & 0.1 & 1.0000 & 0.5 \\
Ratio * Temperature & 18 & 1.0000 & 2.9 & 1.0000 & 2.9 & 1.0000 & 0.1 & 1.0000 & 0.6 \\
Manure * Ratio * Temperature & & & & & & & & &
\end{tabular}

511

512

513

514

515

516

517 
519 Table 2. ANOVA for effects of manure, extraction ratio, and temperature on manure DRP and $\mathrm{NH}_{4}-\mathrm{N}$ leached during snowmelt

520 leaching experiments. Data are presented for mass (mg) as well percent of total $\mathrm{P}$ or total $\mathrm{N}$ applied to funnels in $\underline{\text { as }}$ manure.

\begin{tabular}{lcccccccccc}
\hline \multicolumn{1}{c}{$\begin{array}{c}\text { Source of Treatment } \\
\text { Variation }\end{array}$} & & \multicolumn{2}{c}{ DRP } & \multicolumn{2}{c}{ Percent of Total P } & & NH N $_{4}$ & & Percent of Total N \\
\hline & Df & P-Value & \% Trt & P-Value & \% Trt & P-Value & \% Trt & P-Value & $\%$ Trt \\
Manure & 1 & 0.1006 & 76.7 & 0.6992 & 1.8 & 0.0254 & 53.0 & 0.5713 & 31.1 \\
Placement & 2 & 0.9632 & 1.9 & 0.9981 & 0.0 & 0.9857 & 0.3 & 0.8993 & 19.9 \\
Rate & 2 & 0.9928 & 0.4 & 0.0423 & 87.0 & 0.1710 & 34.8 & 0.9286 & 13.9 \\
Manure * Placement & 2 & 0.8219 & 10.2 & 0.7860 & 5.6 & 0.9903 & 0.2 & 0.9166 & 16.4 \\
Manure * Rate & 2 & 0.9473 & 2.8 & 0.9804 & 0.5 & 0.5693 & 10.4 & 0.9896 & 2.0 \\
Placement * Rate & 4 & 0.9991 & 2.1 & 0.9999 & 0.3 & 0.9993 & 0.6 & 0.9992 & 7.4 \\
Manure * Placement * Rate & 4 & 0.9931 & 6.0 & 0.9787 & 4.9 & 0.9989 & 0.8 & 0.9986 & 9.4 \\
\hline
\end{tabular}

521

522

523

524

525 
527 Table 3. Cumulative Mmanure DRP and $\mathrm{NH}_{4}-\mathrm{N}$ release $(\mathrm{mg})$ for the Arlington Liquid and DFRC semi-solid dairy manures during 528 snowmelt experiments as a function of manure application rate (Low, Medium, High) and manure placement within a snowpack

529 (under snow, between snow layers, and on top of snow). Values in parentheses are DRP and $\mathrm{NH}_{4}-\mathrm{N}$ release expressed as percentages 530 of total P and total $\mathrm{N}$ applied as manure.

531

\begin{tabular}{|c|c|c|c|c|c|c|}
\hline Rate & Under & Between & Top & Under & Between & Top \\
\hline & & DRP & & & $\mathrm{NH}_{4}-\mathrm{N}$ & \\
\hline & $\mathrm{mg}$ & $\mathrm{mg}$ & $\mathrm{mg}$ & $\mathrm{mg}$ & $\mathrm{mg}$ & $\mathrm{mg}$ \\
\hline & & & $\begin{array}{l}\text { Liquid } \\
\text { Manure }\end{array}$ & & & \\
\hline (Low & $6.5 \underline{(13.0)}$ & $9.0 \underline{(18.0)}$ & $10.2(20.4)$ & $74.2 \underline{(21.1)}$ & $89.6 \underline{(25.5)}$ & $74.8 \underline{(21.3)}$ \\
\hline Medium & $6.6(6.6)$ & $9.0(9.0)$ & $8.4(8.4)$ & $145.6(20.7$ & 164.5 & $140.1(19.9)$ \\
\hline \multirow[t]{2}{*}{ High } & $7.0 \underline{(3.5)}$ & $9.2(4.6)$ & $7.1(3.6)$ & $279.8(19.9)$ & $260.7 \underline{(18.5)}$ & 259.6 \\
\hline & & & $\begin{array}{c}\text { Semi-solid } \\
\text { Manure }\end{array}$ & & & \\
\hline Low & $4.7 \underline{(22.4)}$ & $3.4(16.2)$ & $2.8(13.3)$ & $25.1(22.4)$ & $22.8(20.4)$ & 15.9 \\
\hline Medium & $5.4(12.0)$ & 3.8 & $4.3(9.6)$ & 49.7(20.8) & $41.8(17.5)$ & 30.7 \\
\hline High & $5.2(5.7)$ & $4.3(4.7)$ & $4.6(5.1)$ & $90.5(18.9)$ & $86.7(18.1)$ & $64.3(13.4)$ \\
\hline
\end{tabular}

532

533 
536 Table 4. Data for manure solids applied, water:solids ratio, manure total $\mathrm{P}$ and $\mathrm{N}$ applied, and predicted $\mathrm{DRP}$ and $\mathrm{NH}_{4}-\mathrm{N}_{\text {release }}$ for

537 both the liquid and semi-solid manures during the snowmelt leaching experiments.

\begin{tabular}{|c|c|c|c|c|c|c|}
\hline Rate & $\begin{array}{c}\text { Manure } \\
\text { Solids } \\
\text { Applied }^{1}\end{array}$ & $\begin{array}{l}\text { Water:Solids } \\
\text { Ratio }(\mathrm{W})^{2}\end{array}$ & $\begin{array}{l}\text { Manure Total } \\
\text { P Applied }\end{array}$ & $\begin{array}{l}\text { Manure Total } \\
\text { N Applied }\end{array}$ & $\begin{array}{l}\text { Predicted DRP } \\
\text { Release }^{3}\end{array}$ & $\begin{array}{c}\text { Predicted } \\
\mathrm{NH}_{4}-\mathrm{N} \\
\text { Release }^{4}\end{array}$ \\
\hline & $\mathrm{g}$ & $\mathrm{cm}^{3} \mathrm{~g}^{-1}$ & $\mathrm{mg}$ & $\mathrm{mg}$ & $\mathrm{mg}$ & $\mathrm{mg}$ \\
\hline & & & Liquid Manure & & & \\
\hline Low & 4.5 & 331.2 & 49.9 & 352.3 & 8.4 & 78.9 \\
\hline Medium & 9.1 & 174.0 & 99.9 & 704.7 & 10.3 & 146.6 \\
\hline High & 18.2 & 96.4 & $\begin{array}{c}199.8 \\
\text { Semi-solid } \\
\text { Manure }\end{array}$ & 1409.4 & 7.7 & 282.2 \\
\hline Low & 4.0 & 316.0 & 21.3 & 112.7 & 6.1 & 22.8 \\
\hline Medium & 8.6 & 144.0 & 45.3 & 239.5 & 10.6 & 44.7 \\
\hline High & 17.1 & 74.0 & 90.7 & 479.0 & 16.1 & 86.3 \\
\hline
\end{tabular}

${ }^{3}$ Predictions use Eq. [1] for semi-solid manure and Eq. [2] for liquid manure

${ }^{4}$ Predictions use Eq. [3] 